NBER WORKING PAPER SERIES

\title{
PUBLIC PRESCHOOL AND MATERNAL LABOR SUPPLY: EVIDENCE FROM THE INTRODUCTION OF KINDERGARTENS INTO AMERICAN PUBLIC SCHOOLS
}

\author{
Elizabeth Cascio \\ Working Paper 12179 \\ http://www.nber.org/papers/w12179
NATIONAL BUREAU OF ECONOMIC RESEARCH
1050 Massachusetts Avenue
Cambridge, MA 02138
April 2006

This paper has benefited from the comments of Hilary Hoynes, Ethan Lewis, Ann Huff Stevens, and participants at the Second Annual UKCPR Small Grants Conference. This project was supported with a grant from the UK Center for Poverty Research through the U.S. Department of Health and Human Services, Office of the Assistant Secretary for Planning and Evaluation, grant number 5 ASPE417-02. The opinions and conclusions expressed herein are solely those of the author and should not be construed as representing the opinions or policy of the UKCPR or any agency of the Federal government. The views expressed herein are those of the author(s) and do not necessarily reflect the views of the National Bureau of Economic Research.

(C2006 by Elizabeth Cascio. All rights reserved. Short sections of text, not to exceed two paragraphs, may be quoted without explicit permission provided that full credit, including $(\subset$ notice, is given to the source. 
Public Preschool and Maternal Labor Supply: Evidence from the Introduction of Kindergartens into American Public Schools

Elizabeth Cascio

NBER Working Paper No. 12179

April 2006

JEL No. H52, I20, J13, J22

\begin{abstract}
Beginning in the mid-1960s, many state governments, particularly in the South and West, began to subsidize kindergartens for the first time. These initiatives generated wide variation across states over time in the supply of seats for five year olds in public schools. This paper uses the staggered timing and age-targeting of these preschool expansions to examine how the provision of universal child care through public schools affects maternal labor supply. I find that single women with five year olds but no younger children were more likely to be employed once kindergartens were available. The estimated effect is large, implying that three mothers entered the labor force for every ten children enrolled in public school. By contrast, I detect no significant labor supply response among other single women with eligible children or among married mothers of five year olds. These findings complement other research suggesting that preschools targeted toward at-risk populations, such as children in single-parent families, are more cost effective than universal programs.

Elizabeth Cascio

Department of Economics

University of California, Davis

One Shields Avenue

Davis, CA 95616-8578

and NBER

eucascio@ucdavis.edu
\end{abstract}




\section{Introduction}

State and local governments across the United States are either considering or have already passed initiatives to extend public schooling to children under the age of five. While the main benefit of preschool is thought to come through improvements in the longer-run social and economic outcomes of attendees (Barnett 1995; Karoly et al. 1998; Currie 2001), public schooling also provides free child care during the school day. This has prompted some to argue that increases in employment of primary caregivers and reductions in use of public assistance would help offset the cost of universal preschools in the short term (e.g., Gelbach 2002; Karoly and Bigelow 2005). The loss in labor output from an inability of many families to afford high-quality child care may alone be sufficient justification for provision of universal preschools.

But how much does employment - maternal employment in particular - respond to public schooling? Which mothers change their labor supply? Many studies have estimated the sensitivity of maternal employment to child care costs (see Anderson and Levine (1999) and Blau and Currie (2004)), but their elasticity estimates are not easily generalized, in part because free preschools do not provide a pure price subsidy to all mothers (Gelbach 1999). Several recent studies also examine how public preschool availability affects maternal labor supply using quasiexperiments (Baker, Gruber, and Milligan 2005; Berlinski and Galiani 2005; Schlosser 2005). However, these studies are focused on other countries, where mothers arguably have different preferences and different competing child care arrangements. Moreover, while Gelbach (2002) presents estimates of how preschool eligibility influences maternal labor supply in the United States, he employs an identification strategy that has been criticized in other applications.

This paper provides new evidence on these questions by using variation in preschool availability from the introduction of kindergartens into American public schools. Starting in the mid-1960s, many state governments began subsidizing provision of public school kindergarten 
programs for the first time. These funding initiatives generated rapid increases in the probability that school districts operated kindergartens: In most affected states, public kindergartens went from being sporadically available to universal in a matter of three or four years (Cascio 2004). My analysis compares the child care and labor force decisions of women with age-eligible (five-yearold) children around the time these funding initiatives were passed. I construct several comparison groups, taking advantage of the staggered timing of the funding initiatives, as well as the fact that they did not subsidize the care of children who were not age five.

My analysis uses data from the public use microdata samples of the 1950 through 1990 Decennial Censuses. Relative to recent work on related questions using a similar research design (Baker, Gruber, and Milligan 2005; Berlinski and Galiani 2005; Schlosser 2005), the Census allows me to examine pre-initiative trends in employment over a long period, which is key in evaluating the credibility of my differences-in-differences (DD) estimates. The Census also offers large samples, which make it possible to estimate models for different subpopulations and to define narrow comparison groups for a differences-in-differences-in-differences (DDD) type analysis.

I find that the introduction of state aid for kindergartens raised the labor supply of single mothers of five year olds and no younger children, but had no effect on the labor supply of other women with eligible children. For the former, the employment estimates are highly stable across specifications and choice of comparison group. The estimates are also sizable, implying that for every ten children enrolled in public school as a result of the funding initiatives, three mothers entered the labor force. By contrast, for married mothers of five year olds with no younger children, there is not a statistically significant employment response, and estimates are precise enough to rule out effects of the magnitude observed for their single counterparts. The estimates for single and married mothers with children aged five and younger are more sensitive to specification, but hover around zero. For all groups, the introduction of kindergartens led to 
large increases in the public school enrollment, and for most, there was a large and significant movement away from private programs.

These findings suggest that, at most, modern-day preschool expansions in United States will generate positive labor supply responses among single mothers. As a result, it may be more cost effective to target public preschool programs toward at-risk populations. Indeed, although universal preschools make child care accessible to many credit-constrained single parents, they also crowd out private child care that is affordable, particularly for two-parent families. Targeted early childhood interventions may also have longer-run social and economic benefits for children (Barnett 1995; Karoly et al. 1998; Currie 2001; Cunha et al. 2005) that do not exist for lowerintensity universal programs (Cascio 2004).

In the next section, I further distinguish the approach of this paper from the existing literature. Section III describes the kindergarten funding initiatives and formalizes the identification strategy. Section IV describes the Census samples and conducts some preliminary specification tests. Section V presents the results, and in Section VI, I discuss the findings and conclude.

\section{Background}

A well-known empirical regularity in the study of female employment is the strong positive relationship between the age of a woman's youngest child and her labor supply. The probability of that a mother is employed rises steeply between the birth of her last child and when that child turns age six, and remains relatively flat as he continues to age. This suggests that public schooling may make relatively high quality child care accessible to many mothers who would otherwise not be able to afford it on the private market. If so, extending public schooling to younger children may speed a mother's return to paid work. 
Gelbach (1999) formalized this idea. For mothers who would not otherwise be working, public preschool provides a 100 percent price subsidy for child care on the employment margin, increasing the price of leisure relative to private consumption and encouraging women to substitute toward work. For mothers who would otherwise work more hours than the length of the school day, the price subsidy for child care is inframarginal, with a kink in the budget constraint occurring where the number of hours worked is equal to the number of hours in the school day. The effect of public preschool eligibility on maternal labor supply is neither a price nor an income elasticity of employment, but rather a combination of the two.

While important from a policy perspective, identifying the effect of a child's public school eligibility on his mother's labor supply is challenging, since his age might be related to other factors that bear on the mother's decision. Identifying the effect of public preschool availability on maternal labor supply is similarly difficult, since localities that fund preschools are likely doing so in response to demand.

The existing literature has tackled this identification problem in two ways. The first approach attempts to find instrumental variables for a child's eligibility for existing public preschools. For example, five year olds born in the first quarter of the calendar year are significantly less likely to be attending public school kindergarten, in large part because they would have been too young to qualify for school entrance the prior fall (Angrist and Krueger, 1991). ${ }^{1}$ Using quarter of birth as an instrument for the public kindergarten enrollment of five year olds in 1980 U.S. Census, Gelbach (2002) finds that married mothers with children in public kindergarten were more likely to be working and work more hours, regardless of the age of the youngest child in the household. Among single mothers, significant positive responses were limited to those with no children under the age of five.

\footnotetext{
${ }^{1}$ Age in the Census is measured as of April 1. Five year olds born in the first quarter are therefore the youngest five year olds.
} 
While Gelbach (2002) represents a novel attempt to find exogenous variation in public school eligibility, the season of a child's birth may be directly related to his mother's employment status. The invalidity of the quarter-of-birth instrument for schooling was initially suggested for applications where wage was the dependent variable (Bound, Jaeger, and Baker 1995; Bound and Jaeger 2000). More recently, season of (mother's) birth has been shown to have direct effects on infant health (McCrary and Royer 2005), as well as on (own) test scores during high school (Cascio and Lewis forthcoming). Quarter of birth may thus be related to human capital shared by mother and child and therefore not a valid instrument. The approach taken in this paper relies in no way on this source of variation.

The second approach to identification, and the one taken in this paper, exploits variation in the presence of public preschool programs across geographic areas over time - a DD approach. Recent DD studies have focused on preschool expansions in other countries, including Argentina (Berlinski and Galiani 2005), Canada (Baker, Gruber, and Milligan 2005), and Israel (Schlosser 2005). Each of these papers uncovers strong take-up of new preschool seats, though the magnitude and precision of their estimated labor supply responses vary dramatically. Nonetheless, each study finds some evidence that increases in the supply of preschool slots raises maternal employment, if not for married mothers with eligible children (Baker, Gruber, and Milligan 2005; Schlosser 2005), then at least for single mothers with no other children under the age eligibility threshold (Berlinski and Galiani 2005).

One potential problem with these studies is bias from reversion to the mean. In each, data to investigate pre-existing trends in employment are limited, if not lacking completely, making it difficult to conclude that gains in maternal labor force participation in treated areas would not have occurred absent the program. In fact, in two of the studies (Berlinski and Galiani 2005; Schlosser, 2005), the variation in preschool availability derives from centrally-administered 
programs, which built more preschools in areas that initially had fewer or lower pre-existing levels of maternal employment. The positive labor supply response to these programs in particular may reflect a return to some longer-run trend, rather than a true policy impact. ${ }^{2}$

An advantage of the present analysis is that the Census data allow me to investigate preinitiative trends in maternal employment over a long time frame in an attempt to rule out this source of bias. In particular, I use Census data dating to 1950 - more than 15 years before the modern wave of U.S. kindergarten expansion began. With these data, I test whether there were significant deviations in maternal employment from its long-run trend in the years immediately preceding the initiatives. I also test whether the funding initiatives can predict maternal observables; ideally, this is not the case, as discussed in the next section. Both of these exercises highlight the difficulty of uncovering credible estimates in this type of application.

Other advantages of this study come from the large samples available in the Census. For example, like Gelbach (2002), I have sample sizes sufficient to conduct separate analyses by marital status and age of a woman's youngest child. For the DDD analyses, I am also able to define very narrow comparison groups of mothers. In existing work, additional comparison groups include essentially all mothers without age-eligible children, presumably due to small samples, not due to their actual comparability. Thus, the available data and the specification checks I perform make it possible to arrive at estimates that are potentially less biased than those previously presented.

As noted above, the parameter estimated in this paper is also useful in thinking about extensions of public schooling to younger children in the United States. The true responsiveness of U.S. women to the provision of free child care through public schools is likely to differ

\footnotetext{
${ }^{2}$ Schlosser (2005) does present evidence that trends in pre-existing employment were statistically indistinguishable in her treatment and comparison areas. However, this could be due in part to small samples. Also, she only has a few years of pre-treatment data, so it may still be the case that there is a deviation from longer-run trend employment in the years preceding the intervention.
} 
dramatically from that of women in other countries, making it difficult to generalize prior DD studies — even if unbiased for the parameter estimated - to the U.S. context. Moreover, the parameter of interest in this paper is arguably an upper bound on the positive employment effect of modern-day preschool expansion. Because of increases over time in women's labor force participation (particularly that of married women), the child care subsidy implicit in public schooling is today more likely to be inframarginal.

\section{Identification Strategy}

\section{A. State Kindergarten Funding Initiatives}

Table 1 shows the year of first state funding for kindergartens in the United States, focusing on states that did not have funding regimes in place by the mid-1960s (hereafter referred to as the "treated states" or the "treated region"). ${ }^{3}$ The vast majority of initiatives passed over the subsequent decades incorporated kindergartens into school foundation aid programs; the remaining initiatives were special appropriations. Most initiatives were passed in the late 1960s and early 1970s, though there is considerable variation in timing across states.

The typical school district in the treated region, which essentially consisted of the South and West, relied heavily on state funding for education, so the grants covered a substantial fraction of the costs of operating kindergartens. ${ }^{4}$ Not surprisingly, school districts responded rapidly to funding availability, and as a result, there was widespread variation across states and over time in kindergarten supply. Figure 1 shows this in a manner consistent with the Decennial Census data, plotting the fraction of school districts with kindergartens by year and decade of the

\footnotetext{
${ }^{3}$ See Cascio (2004) for sources.

${ }^{4}$ For example, in 1965, the average Southern school district derived 53 percent of its revenue from state grants (U.S. Department of Health, Education, and Welfare 1968).
} 
initiative. ${ }^{5}$ The role of state funding is particularly apparent for the 1970s and 1980s adopters, which exhibited similar trends in public school kindergarten provision in the 1960s, but widely divergent trends thereafter. It is less clear for the states that funded kindergarten for the first time during the 1960s. However, most states in this group passed initiatives late in the decade, and take-up by all districts in a state usually took three or four years (Cascio 2004).

\section{B. Empirical Models}

My empirical strategy takes advantage of the state-time variation in kindergarten supply induced by the funding initiatives. Given the observations from Figure 1, my preferred policy variable is the share of the previous four years that a kindergarten funding regime has been in place, rather than just an indicator for the presence of a regime. This measure allows me to exploit differences in initiative timing that would otherwise be impossible using data on ten-year intervals. ${ }^{6}$ I do not employ the kindergarten supply measure of Figure 1 directly, because the pace at which school districts implemented kindergartens was likely to have been a reflection of demand.

I begin with a DD model that is otherwise similar to those previously estimated in the literature:

$$
y_{i s t}=\theta \text { share }_{s t}+\beta^{\prime} X_{i s t}+\alpha_{s}+\gamma_{t}+\varepsilon_{1 i s t} \text {, }
$$

\footnotetext{
${ }^{5}$ The trends in Figure 1 were calculated using state panel data on the fraction of primary school districts offering kindergarten. Annual averages are weighted with contemporaneous state enrollment in first grade. The data are described in the Data Appendix.

${ }^{6}$ It took around four years for full take-up of the funding initiatives, as discussed in reference to Figure 1. (See also Cascio 2004.) States which have had their funding initiatives in place for four years or less at a given point in time are therefore likely to exhibit a lot of variation in kindergarten supply. As suggested by Figures 2 and 3 (below), results are nonetheless qualitatively similar when I use an indicator for the presence of state funding for kindergarten. These findings are available from the author upon request.
} 
where $y_{i s t}$ is some employment measure for mother $i$ in state $s$ in Census year $t, X_{i s t}$ is a vector

of controls (discussed below); and $\alpha_{s}$ and $\gamma_{t}$ represent state and year fixed effects, respectively.

The $\alpha_{s}$ remove fixed differences across states in maternal employment (for example, due to

differences in norms), while the $\gamma_{t}$ account for common shocks to maternal employment (for

example, due to federal programs). As described above, share st is the fraction of years over $t-4$

to $t$ - 1 that the initiative has been in place in state $s$; thus, share ${ }_{s 1970}=0.75$ for states that passed

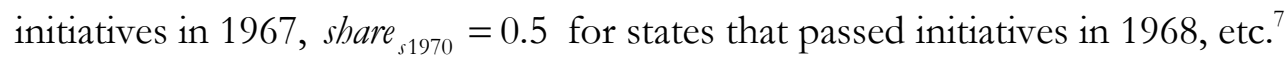

The parameter of interest in (1) is $\theta$, which is the change in maternal employment

associated with full implementation (4+ years) of the state's kindergarten funding program. It is important to note that a one unit increase in share ${ }_{s t}$ does not necessarily mean that a state went from having no kindergartens to universal availability. Instead, full implementation of the funding program, so defined, was associated with a 61 to 65 point percentage point increase in kindergarten supply in the average state. ${ }^{8}$ Some localities operated kindergarten programs before state funding was made available, and since no mandate for kindergarten provision accompanied the initiatives, other districts may have taken more than four years to respond.

I am primarily interested in estimating (1) for mothers of five year olds. Estimates of $\theta$ will be identified if the introduction of funding for kindergarten programs was not otherwise related to their employment, conditional on the fixed effects and observables. Given that current

\footnotetext{
${ }^{7}$ The Census is taken in the spring of the year, so the relevant academic year begins the prior fall. 8 These estimates come from a regression of the fraction of school districts in a state with kindergarten programs on share using data from 1966 (the first available year), 1969, 1979, and 1989. In a model with state and year fixed effects, full implementation of the program is associated with a 0.646 increase in the fraction of school districts operating kindergarten programs (standard error of 0.157). In a model that also includes state-specific linear trends, full implementation of the program is associated with a 0.608 increase in the fraction of school districts operating kindergarten programs (standard error of 0.199). (Data are described in the Data Appendix. Standard errors are clustered on state of residence.)
} 
(and expected) maternal employment could have played a role in the decision of states to pass initiatives, this may be a very strong assumption. ${ }^{9}$ However, there are several ways to examine its credibility. For example, if share $_{s t}$ does not predict $\varepsilon_{1 i s t}$, it should also not predict maternal observables which are directly related to employment, $X_{i s t}$, as suggested above. The funding initiatives should also not be associated with the employment of mothers without kindergarteneligible children, or shocks to employment before they are passed, as also noted in the previous section.

I implement each of these specification tests below, and the results suggest that estimates of $\theta$ from (1) would be biased for at least some subpopulations under consideration. I confront this problem in two ways. I first add smooth state-specific trends to (1). Because a linear trend appears too restrictive over the long time period under consideration, I include a state-specific quadratic in year:

$$
y_{i s t}=\theta \text { share }_{s t}+\beta^{\prime} X_{i s t}+\alpha_{s}+\gamma_{t}+\delta_{1 s} t+\delta_{2 s} t^{2}+\varepsilon_{2 i s t}
$$

This model removes biases from unobservable determinants of kindergarten supply and employment that are trending smoothly over time within states. ${ }^{10}$ Of course, estimates of $\theta$ from (2) will only be identified if the smooth state trend is sufficient for all remaining sources of bias. I examine this assumption using the same specification tests described above.

My second approach is to estimate a DDD model on a broader sample of mothers:

$$
\begin{aligned}
y_{i s t}=\theta \text { share }_{\text {st }} \text { five }_{i}+\theta_{2} \text { share }_{s t} & +\beta_{1}^{\prime} X_{i s t}+\beta_{2}^{\prime} X_{i s t} \text { five }_{i} \\
& +\alpha_{1 s}+\alpha_{2 s} \text { five }_{i}+\gamma_{1 t}+\gamma_{2 t} \text { five }_{i}+\varepsilon_{3 i s t}
\end{aligned}
$$

\footnotetext{
${ }^{9}$ State legislative records suggest that, if anything, the belief that kindergartens would provide free child care was an impediment to the funding initiatives being passed. Instead, the stated goal of the most state kindergarten programs was to reduce grade repetition and other early signs of school failure (Cascio 2004). ${ }^{10}$ Results are qualitatively similar when I include a cubic. I only have five years of Census data, however, so the estimates become somewhat noisy.
} 
where five $_{i}$ is an indicator for whether mother $i$ has a five-year-old child. Below, I focus on estimates of (3) using two different comparison groups: mothers of slightly younger children (ages three and four) and mothers of slightly older children (ages seven and eight). Estimates of $\theta$ - the difference in DD estimates of the treatment and comparison groups - are identified provided that there are no employment shocks that both coincide with the initiatives and are unique to women with kindergarten eligible children. A more general version of (3) replaces $\theta_{2}$ share $_{s t}$ with a state-by-year fixed effect. I estimate this version of the model as another robustness check. I also conduct all feasible specification tests, but in triple-difference form.

\section{Extensions}

Throughout the paper, I present separate estimates by marital status of the mother and age of her youngest child. Because of differences in preferences and the constraints facing these women, the introduction of kindergartens might have had different effects on their employment decisions. For example, as well documented for more recent years (Anderson and Levine 1999; Blau and Currie 2004; Rosenbaum and Ruhm 2005) the fraction of family income devoted to child care is much higher for single women. The same appears to have held during the period of interest, suggesting that the introduction of kindergartens would have generated a larger relative price shock for single mothers. ${ }^{11}$ Similarly, mothers of five year olds with no younger children would have experienced a relatively large reduction in child care costs.

I also estimate models similar to those above for the public and private school enrollment status of matched children. These models serve several purposes. First, they help to demonstrate that the kindergarten programs introduced in response to the initiatives did indeed

\footnotetext{
${ }^{11}$ For example, using data on formal child care costs from Coelen et al. (1976), Gelbach (2002) concludes that availability of kindergarten would have provided at least a 13 percent increase in the typical single (working) mother's effective hourly wage in 1980, provided that she would have paid for child care.
} 
represent a shock to the price of child care, which would not have been the case if there were already very inexpensive child care options deemed highly substitutable. Unfortunately, data on child care use, cost, and quality are very limited for this period. ${ }^{12}$ In the very least, however, the introduction of free kindergartens should have induced an exodus of five year olds from private schools to public schools. Second, and related, these models are useful in quantifying the extent to which universal preschools "crowd out" child care options on the private market. Finally, the models for public school enrollment are useful in establishing that kindergarten availability only affected the enrollment of age-eligible children.

\section{Data}

\section{A. Sample and Key Variables}

The primary data for this analysis are drawn from the 1950 to 1990 Decennial Census Public Use Microdata (PUMS). These data are comparable over the period spanning the kindergarten funding initiatives, allowing me to construct consistent repeated cross sections on maternal labor supply and child enrollment status. Because the Census includes entire households, not just individuals, I am also able to conduct separate analyses by the age structure of children in a family, as described above. The Census also offers large samples and information on state of residence, which are lacking in higher frequency data for this period. ${ }^{13}$

\footnotetext{
12 However, the existing evidence (largely from supplements to the Current Population Survey) supports the claim that kindergartens lowered the price of some fixed quality of care. For example, in early 1975, nearly a quarter of working mothers (and nearly a third of full-time working mothers) used formal day care or care from a non-relative when their five year olds were not in school (Waite 1976). Care by other relatives - the most common alternative - was also not always free: in the late 1970s, for instance, well over half of working mothers with young children paid for child care from other relatives (Lueck, Orr, and O'Connell 1982).

${ }^{13}$ For example, while annual, the Current Population Survey lacks complete information on state of residence prior to 1977. Sample sizes are also considerably smaller than those available in the Census.
} 
I use the one-percent samples from 1950 and 1960 Census PUMS, the one-percent Form 2 state PUMS from 1970, and the five-percent PUMS from 1980 and 1990. All means and regressions are weighted so as to be representative of the population. ${ }^{14}$ My primary sample includes five and six year olds and their mothers, for whom there is no allocation in key employment variables (described below) or in the ages of any matched children, ages 0 to $17 .^{15} \mathrm{I}$ create analogous samples of women without five or six year olds but with children of other ages (three and four, and seven and eight) for the DDD analyses. ${ }^{16}$ Because of their relative similarity, I limit the analysis to mothers and children residing in the treated region. ${ }^{17}$

Because of how age is measured in the Census, I consider both five and six year olds to be eligible for kindergarten. In particular, age in the Census is measured as of April 1, though in most states, school entry regulations require entering kindergartners to reach age five by some specified date between September and January. ${ }^{18}$ As a result, some children aged five as of April 1 (those born in the second and third quarters of the year) and some children aged six as of April 1 (those born in the fourth and first quarters of the year) would have been eligible to start kindergarten the prior fall. ${ }^{19}$ Below, I refer to the samples of five and six year olds as "five year olds" or "eligible" children for ease of exposition.

\footnotetext{
${ }^{14}$ In the employment regressions, I use maternal person weights (1950 and 1990 only). In the child enrollment regressions, I use child person weights (1950 and 1990 only). The samples from 1960, 1970, and 1980 are self-weighting.

${ }^{15} \mathrm{My}$ primary reason for dropping allocated data is to remove noise in the labor supply estimates. However, because the outcomes are either binary (the employment indicator) or bounded (hours worked), measurement errors are "non-classical," with the signal (negatively) correlated with the noise. As a result, using allocated employment data would also tend to bias the least squares coefficients (Hausman 2001). 16 The vast majority of mothers in the sample are either household heads or the wives of household heads; the remaining mothers are in subfamilies.

17 When I include women from non-treated states in the analysis, the specification tests conducted below fail much more frequently and with much greater strength.

${ }^{18}$ Ideally, I would redefine age to be more consistent with the year in which a child would have entered school. However, this approach is not feasible for this application, since data on quarter of birth are only available in the 1960, 1970, and 1980 Censuses.

${ }^{19}$ On the other hand, some five and six year olds would not have been eligible to enter kindergarten, biasing downward the reduced-form estimates of the effect of the funding initiatives on maternal
} 
My analysis focuses on two measures of current employment that are observed in all

Census years: an indicator for whether a mother was working and hours worked, both measured as of the week prior to the Census. ${ }^{20}$ My regressions include controls for maternal race (indicators for black and other race), quadratics in the number of children each mother has in different age categories (ages zero to four, age five, age six, ages seven to 12, and ages 13 to 17), and a quadratic in maternal age. I do not control for maternal education, because it is not available in the person records of the 1950 Census. ${ }^{21}$ However, for most subpopulations and specifications, the initiatives cannot predict maternal education where observed, as shown below. Limiting the analysis to data from 1960 and later and controlling for education also yields results very similar to those presented below.

\section{B. $\quad$ Summary Statistics and Preliminary Specification Tests}

Table 2 shows trends in the employment of women with five year olds, by marital status and the presence of younger children in the family. As mentioned above, the samples are limited to women residing in treated states. The sample replicates the well-known rise in labor supply of married mothers that began in the early 1970s. In 1970, the employment rate of married women with no children under age five was 37 percent, having risen only 7 percentage points over the previous decade. By 1990, their employment rate had risen to 64 percent and was nearly at parity to that of single women with no younger children. Increases in the employment rate of married

employment. However, the indirect least squares effect of child enrollment on maternal employment (the parameter estimated in Gelbach (2002)) remains identified under the assumptions laid forth above. ${ }^{20}$ In 1960 and 1970, hours worked are presented in intervals. To make the hours variable comparable across years, I first create the same intervals using the continuous hours variables in 1950, 1980, and 1990. In each year, I then assign each mother the 1980 sample mean hours worked from her respective interval. These conditional means are calculated using data from only the estimation sample. The estimates are similar when I apply conditional mean hours worked from 1950.

${ }^{21}$ Education is available in the "sample line" records of the 1950 Census. However, the number of sample line respondents is quite small. 
mothers with younger children were even more dramatic, rising from more than two-fold from only 23 percent in 1970 to 48 percent in 1990. For single mothers, increases in employment over the same period were much less striking. Nonetheless, like married women, single mothers with no children under five experienced a relatively large increase in employment during the 1970s, when many of the kindergarten funding initiatives went into effect.

The remaining columns of Table 2 test whether there were significant shocks to maternal employment before the kindergarten funding initiatives were passed-one of the three specification tests discussed above. In particular, column (6) presents coefficients (robust standard errors) on pre $_{s t}$ from the model:

$$
y_{i s t}=\theta \text { share }_{s t}+\tau \text { pre }_{s t}+\beta^{\prime} X_{i s t}+\alpha_{s}+\gamma_{t}+\varepsilon_{4 i s t},
$$

where pre $_{s t}$ is an indicator for the Census year immediately prior to a state's initiative. ${ }^{22}$ The estimates in column (7) are from a version of equation (4) that includes quadratic state trends. ${ }^{23}$ If anything, the evidence of prior shocks to employment is stronger in the second model. Married women with no children under five were significantly more likely to be working and worked significantly more hours in the Census year pre-initiative; point estimates on pre $_{s t}$ for single women are of a similar magnitude, but not precise. A state's decision to fund public school kindergartens thus appears to have come in part in response to a (potentially temporary) positive shock to demand.

The next two tables present average maternal background characteristics by Census year and test whether they can be predicted by the funding initiatives_-another specification check discussed above. As in Table 2, estimates in column (6) are from a model that only includes

\footnotetext{
22 Thus, for states which passed initiatives in the 1960s, pre $_{s 1960}=1$ and $\operatorname{pre}_{s t}=0$ for $t \neq 1960$; for states which passed initiatives in the 1970s, $\operatorname{pre}_{s 1970}=1$ and $\operatorname{pre}_{s t}=0$ for $t \neq 1970$, etc.

${ }_{23}$ These regressions are weighted by population weights, and standard errors are consistent for heteroskedasticity and correlation in the error terms over time within state.
} 
state and year fixed effects, while estimates in column (7) add a quadratic state trend. For single mothers of five year olds with no younger children (Table 3), I find no significant relationships between background characteristics and the funding initiatives. For single women with five year olds and younger children (also Table 3), there are some significant associations - particularly in column (6) - in part because estimates are more precise. Significant relationships between observables and the program arise with similar frequency for married mothers of five year olds (Table 4), suggesting that there may also be unobservable factors confounding the DD estimates. This preliminary analysis suggests that the DD specifications - even those with smooth state trends - are likely to yield biased estimates of the program's effect. The remaining columns of Tables 2 through 4 present analogous specification tests for the DDD models. For example, the last two columns of Table 2 show the difference in estimated $\tau$ 's (from model (4)) between the treatment and comparison groups. Column (8) shows this difference when the comparison group consists of women with three and four year olds, while column (9) shows it when the comparison group consists of mothers of seven or eight year olds. ${ }^{24}$ Similarly, the last two columns of Tables 3 and 4 test whether the each of these comparison groups experienced the same trends in observables as the treatment group when the initiatives were passed.

For two of the four subpopulations under consideration, the DDD models appear unambiguously to provide for better comparisons. For married women with no younger children, treatment-comparison differences in pre-initiative employment shocks are small and no longer statistically significant (Table 2). Moreover, the observable characteristics of treated mothers appear to have been trending quite similarly to those of at least one of the comparison groups - married women with three or four year olds (Table 4, column (8)). For single mothers

\footnotetext{
${ }^{24}$ Throughout, comparison groups are defined to be as similar as possible to the subpopulation under consideration. For example, when considering single mothers with no younger children, a comparison group would consist of single mothers with seven or eight year olds, no five or six year olds, and no younger children.
} 
with no younger children, mothers of seven or eight year olds appear to provide a relatively good comparison group, with pre-initiative shocks to hours worked (Table 2, column (9)) and trends in observables (Table 3, column (9)) being nearly identical.

By contrast, for mothers of five year olds with younger children, the DDD models at best perform as well as the DD models and at worst are more biased. For example, mothers of seven and eight year olds appear to provide a relatively decent comparison group for single women with children who are kindergarten eligible and younger. However, the positive pre-initiative shocks to employment are persistent for this group (column (9) of Table 2), suggesting that mean reversion may still be a problem. For married women with younger children, neither comparison group appears to provide for less biased estimates than the DD models.

\section{Results}

I begin this section with the findings for single women. I then discuss the results for married women. Throughout, regressions are weighted by population weights, as noted above, and standard errors are consistent for heteroskedasticity and correlation of error terms within states over time. All regressions also include state fixed effects, year fixed effects, and a vector of maternal background controls. ${ }^{25}$ For completeness, I present all specifications for each subpopulation.

\section{A. Effects for Single Women}

Table 5 presents estimates of the effect of kindergarten availability on the employment of single women with kindergarten eligible children. For those without any other children younger

\footnotetext{
25 This vector includes indicator variables for whether the mother is black or of another race (not white), a quadratic in maternal age, quadratics in the number of (own) children in different age categories (zero to four, five, six, seven to 12 , and 13 to 17 ).
} 
than five (upper panel), estimates of the effect of state funding are quite similar across specifications. In the DD model with trends (column (3)), full implementation of the program is associated with an 8.1 percentage point increase in the likelihood of working and 3.23 more hours worked in the prior week - effects that are only slightly larger than those from the DD model without trends (column (2)). None of the DD estimates are statistically significant. However, the DDD estimates are quite similar in magnitude and in general more precisely estimated. For example, when compared to single mothers with seven or eight year olds and no younger children - argued above to be the better of the two comparison groups for this subpopulation - the program is associated with a marginally significant 7.3 to 7.6 percentage point increase in employment and a significant 3.1 to 3.3 hour increase in weekly hours worked (columns (6) and (7))..$^{26}$

There are several different ways to interpret the magnitude of these estimates. When compared to pre-initiative means, they imply a 13 percent increase in the likelihood of employment and a 14.7 percent increase in hours worked. However, this does not imply that the elasticity of employment with respect to the price of childcare is -0.13 to -0.147 , as not all mothers with eligible children and on the extensive employment margin received a 100 percent price subsidy for child care from the program. Instead, given the estimated effect of the initiatives on kindergarten supply (Section III), a lower bound on the child care price elasticity for this subpopulation is $-0.2 .^{27}$ Using the estimated effect of the program on enrollment (Table 6) and assuming 100 percent take-up of new kindergarten seats, I calculate an upper bound elasticity

\footnotetext{
${ }^{26}$ The second DDD specification includes state-year fixed effects instead of a direct effect of share. ${ }^{27}$ As discussed earlier, full implementation of the funding program was associated with a 61 to 65 percentage point increase in kindergarten supply. Assuming that 65 percent of mothers received a 100 percent subsidy for child care price subsidy on the extensive margin of employment (or the average mother received a 65 percent subsidy), the price elasticity of employment would be equal to $13 / 65$, or approximately 0.2 .
} 
of $-0.55 .^{28}$ These elasticity estimates are on the upper end of those found in the literature on child care costs and maternal labor supply more generally (see Anderson and Levine 1999; Blau and Currie 2004).

Another way of interpreting the estimates is to calculate the effect of enrollment - or take-up of the child care subsidy implicit in kindergarten provision - on maternal employment, the parameter presented in Gelbach (2002). To that end, Table 6 shows how full implementation of the funding program affected the school enrollment of children with single mothers. ${ }^{29}$

Columns (2) and (3) present estimates of the DD models with and without trends, while columns (4) and (5) present DDD models using seven and eight year olds (with no five or six year old siblings) as a comparison group. The initiatives increased the public enrollment rates of five year olds with no younger siblings by 19 to 24 percentage points (39 to 50 percent). Thus, for every ten eligible children enrolled in public school as a result of the initiatives, about three single mothers with no children under five entered the workforce $(0.073 / 0.238 \approx 0.30)$, and enrollment of a five year old in public school allowed the typical single mother with no younger children to work 13 more hours per week $(3.133 / 0.238 \approx 13){ }^{30}$

These effect sizes are larger than those found by Gelbach (2002) for this subpopulation using Census data from 1980, but a different research design. The specification tests conducted

28 As shown in the last column of Table 6, full implementation of the program was associated with a 23.8 percentage point increase in the public school enrollment of five and six year olds. Assuming that 23.8 percent of mothers received a 100 percent subsidy for child care price subsidy on the extensive margin of employment, the price elasticity of employment would be equal to $13 / 23.8$, or approximately 0.55 .

${ }^{29}$ In 1950, enrollment information is limited to "sample line" respondents. The 1950 enrollment question also does not distinguish between public and private schools. In 1960, enrollment data are only available for children age five and over as of the Census. As a result, I limit the enrollment regressions to children aged five and over who are observed between 1960 and 1990. Because I use 1950 data in the employment regressions and women with three and four year olds as an additional comparison group, I do not present instrumental variables results.

${ }^{30}$ Suppose that there was no effect on hours for women already working. (I do not estimate the effect on hours conditional on employment because of concerns about sample selection bias.) In this case, the estimates would imply that, for every ten children enrolled as a result of the funding initiatives, three single mothers entered the labor force full time $(0.3 * 40$ hours $=12$ hours $)$. This does not seem unreasonable, given that a large fraction of the kindergartens founded in response to the initiatives were full day. 
above nonetheless suggest that my estimates are credible. Table 7 (upper panel) further supports this conclusion, testing whether the funding initiatives were associated with changes in employment and child enrollment in the non-treated population. DD estimates of the program's effect on employment of single mothers of three and four year olds (and no five or six year olds) are relatively close to zero in magnitude (columns (2) and (3)). The same is true for mothers of seven and eight year olds, but no younger children (columns (5) and (6)). For the latter group, it is also possible to estimate the effect of the program on enrollment of matched children. As expected, the kindergarten funding initiatives exhibit no association with enrollment of older children.

Figure 2 provides graphical support of these findings, plotting employment and public school enrollment rates for this subpopulation by Census year and decade of kindergarten funding adoption. Panel B shows that trends in the public school enrollment rates of five year olds mirror trends in kindergarten supply, shown in Figure 1. Although noisier, trends in employment of single mothers with no children under five do as well: As shown in Panel A, the decade in which a state began funding kindergartens was met with a relatively large gain in employment. This is particularly noticeable for the 1960s and 1970 s adopters, who receive most of the weight in the estimates. However, it is not the case for single mothers in either of the comparison groups (Panels C and D).

The labor supply responses to the program for these mothers came at least in part from how kindergartens changed the price of child care. In particular, increases in the public school enrollment of five year olds were met with large movements away from private programs (Table 6). The implied substitution of public for private programs was near complete: Full implementation of the kindergarten funding initiatives was associated with reductions in private school enrollment of 9.5 to 10.2 percentage points on a base of 11 percent (upper panel). Thus, 
even in a subpopulation where public interventions in the child care market matter a lot on the extensive employment margin, public child care options appear to crowd out private ones.

For single mothers of five year olds with younger children, there is no evidence that the introduction of public school kindergartens raised labor supply. As shown in Table 5, estimates of the program's effect are negative and statistically insignificant, even in the more credible specifications for this group. For example, in the DDD models using mothers of seven and eight year olds as a comparison group (lower panel, columns (6) and (7)), point estimates on share are -0.026 for employment and -0.319 to -0.440 for hours worked. Moreover, it is possible to rule out positive effects that are probable for single mothers without younger children. On the employment estimate, the upper bound of the (robust) 95 confidence interval is 0.066 ; on the hours estimate, it is 3.15. Although these estimates could be biased downward from mean reversion or from the use of inadequate comparison groups, the suggestion that this group exhibits no behavioral response to the program is not unreasonable. Gelbach (2002) also finds no labor supply response for this subpopulation.

\section{B. Effects for Married Women}

Tables 8 through 10 are analogous to Tables 5 through 7, but pertain to married women. Consider first the reduced-form employment estimates for married women with eligible children but no children under five (upper panel of Table 8). For this group, the DDD estimates using the comparison group of mothers with three or four year olds are the most credible of the specifications, as argued above. As shown in columns (4) and (5), these estimates are positive, but statistically insignificant and very small. Specifically, the kindergarten funding initiatives were associated with a 0.3 to 0.8 percentage point increase in employment and a 0.092 to 0.286 increase in hours worked. 
The magnitude of these estimates can be interpreted with the same metrics used above. When compared to pre-initiative means (Table 8 column (1)), for example, the estimates imply only 0.7 to 2.2 percent increases in both employment measures. These estimates and their counterparts for public school enrollment (Table 9, upper panel) also imply that, for every one bundred children enrolled in public school fewer than four married women with no younger children entered the labor force - an effect size smaller than that found by Gelbach (2002) for the same subgroup. The estimates are also precise enough to rule out effects as large as those found for single women with no younger children — another way in which the estimates of this paper differ from those in Gelbach (2002). In particular, robust 95 percent confidence intervals on the labor supply estimates suggest that increases in employment and hours exceeding 10 percent of the pre-initiative mean are highly improbable. On the same account, it also highly unlikely that more than two mothers entered the labor force for every ten children who enrolled in school as a result of the initiatives.

Figure 3 makes clear why there is no effect of the program on labor supply for this subpopulation. Whereas the employment rates of single women with five year olds and no younger children rose relatively quickly in the decade of first state funding for kindergarten, the same is not true for married mothers. As shown in Panel A, trends in the employment rates of married women with eligible and no younger children were quite similar across adoption decades. Their employment trends also look very similar to those of the comparison groups (Panels $\mathrm{C}$ and D), despite the fact that public school enrollment of matched five year olds responded to the program (Panel B).

For married women with younger children, the most credible estimates of the program's effect are, if anything, smaller. Recall that for this subpopulation, neither of the comparison groups for the DDD models appeared to be valid. Indeed, there were significant differences in 
pre-initiative shocks to employment between the treatments and comparisons (columns (8) and

(9) of Table 2), suggesting that the DDD estimates could be biased by mean reversion.

Consistent with this, I find positive DDD estimates that are larger in magnitude for this group than for married mothers of five year olds without younger children (columns (6) and (7)) - a behavioral response that would not have been predicted by economic theory. The DD estimates (column (2), Table 8) for this subpopulation are also not credible, as the same specification predicts negative effects for the comparison groups (columns (2) and (5), lower panel of Table 10). Instead, the DD estimates with trends (column (3), Table 8) are perhaps the most believable. These estimates are essentially zero (-0.003 for the likelihood of employment and -0.036 for hours worked the previous week).

In addition to the lack of employment responses to the program from married women, the introduction of kindergarten programs appears to have significantly crowded out private child care and education. Table 9 shows that increases in public enrollment and reductions in the private enrollment of their children are quite similar to those observed for the children of single mothers of five year olds with no younger children. Full implementation of the program raised the public enrollment rates of children in intact families by at least 23 percentage points ( 53 percent), and reduced their private enrollment rates by at least 9.3 percentage points (72 percent).

\section{Discussion}

This paper has demonstrated how the introduction of kindergarten programs into American public schools affected the labor supply of women with five-year-old children. I have improved upon recent work in this area by employing a very large data set, which has yielded ample pre-initiative data and narrowly-defined comparison groups, and by performing a number of specification checks that have been generally been neglected. My research design also 
provides an alternative set of estimates to Gelbach (2002), which is to my knowledge the only other paper examining how public preschools affect maternal labor supply in the United States.

I find that single mothers with a kindergarten eligible child and no younger children exhibited a strong employment response to the program. For this subpopulation, reduced-form effects of the state kindergarten funding initiatives are consistent with a child care price elasticity of employment between -0.2 and -0.55 , and a 30 percentage point increase in the likelihood of employment with the enrollment of an eligible child in public school. By contrast, I find no evidence that opening public school kindergartens raised the employment of married mothers of five year olds, or of single mothers with children under the age of five. For nearly all subpopulations, however, there is evidence that universal public kindergartens led to significant crowd-out of private care and education.

These results differ from those in Gelbach (2002), who finds significant employment effects of kindergarten eligibility among married women, regardless of the ages of other children in the family. His estimates for married women and for single women with no younger children are also quite similar in magnitude, which is not the case in the present study. The differences in our findings may result from the fact that I am using variation in kindergarten availability beginning in the mid-1960s, while Gelbach (2002) only uses variation in kindergarten eligibility in the 1980 cross-section. However, differences in our findings could also arise from biases that are present in one study but not the other. On this front, it is worth noting that my estimates are heavily weighted toward responses on extensive margin of employment and as a result, should if anything be larger than those presented in Gelbach (2002), particularly for married mothers.

The questions of whether and how public schooling affects maternal labor supply are critical to understanding the relative merits of universal, as opposed to targeted, preschool programs. Indeed, in the vast majority of states, the debate today is not over whether to fund pre- 
kindergarten programs, but rather which children should be eligible to attend. ${ }^{31}$ Universal programs are likely to involve a reallocation of resources away from the neediest children, for whom the social benefits of preschool are arguably relatively great. The present study implies that the labor supply responses to preschool availability are also relatively great among their mothers, particularly when there are no other younger children in the household. As a result, continuing to target state-financed preschool programs toward children in credit-constrained families - and perhaps widening their age eligibility limits - may be a more socially desirable alternative to universal access.

\section{Data Appendix}

\section{Census Samples}

The data used in this paper were drawn from the 1950, 1960, 1970, 1980, and 1990 Decennial Census Public-Use Microdata Samples (PUMS). The raw data were downloaded from ICPSR. I use the 1950 PUMS (ICPSR Study No. 8251), the 1960 one-percent sample (ICPSR Study No. 7756), the 1970 Form 2 State sample, which is also a one percent sample of the population (ICPSR Study No. 18), the 1980 State (A) five percent sample (ICPSR Study No. 8101), and the 1990 five percent sample (ICPSR Study No. 9952).

I begin by limiting the samples to households residing in one of the 24 states that passed a kindergarten funding initiative after 1965 (listed in Table 1). Children between the ages of 0 and 17 were then matched to their mothers in each Census year. A child was classified as either a child of the householder or a child in a subfamily. The first type of child was matched to either the spouse of the householder or to the householder herself. The second type of child was

31 Today, forty-three states have pre-K programs in operation, and state programs serve at least 900,000 children - as many three and four-year-olds as served by the federal Head Start program. The vast majority of these programs are indeed targeted toward at-risk groups, but several states (such as Georgia and Oklahoma) have universal programs. 
matched to either the wife or primary individual within the same subfamily. For the analysis, the matched sample was limited to children between the ages of 3 and 8 and their mothers.

\section{Data on Kindergarten Supply}

Data on grade span were used to construct the fraction of districts offering kindergarten programs in Figure 1. These data were drawn from both published tabulations and computercoded microdata. Published, state-specific tabulations of grade span based on the universe of school districts were drawn from Education Directory: Public School Systems (1967/68-1970/71). Microdata for the universe of public school districts was available at ICPSR for various academic years from 1972/73 forward: Elementary and Secondary General Information System (ELSEGIS): Public School District Universe Data (1972/73-1979/80, not including 1974/75), Common Core of Data: Public School Districts (1980/81-1983/84), Common Core of Data: Elementary/Secondary Education Agencies (1985/86), and Common Core of Data: Public Education Agency Universe (1986/87-1990/91). The universe of education directory microdata consists of all public school districts beginning in academic year 1969/70; the data is not, however, available in computer-coded format until $1972 / 73$.

To create the longest possible consistent series, the published tabulations of grade span for 1967/68 through 1970/71 were replicated using the microdata for later years. Specifically, the published tabulations included the following grade span categories: K-6, 1-6, K-8, 1-8, K-9, 1-9, $\mathrm{K}-12,1-12,7-12,9-12$, and other. School districts were similarly categorized by grade span at the state level from 1972/73 through 1990/91. For each state in a given year, the number of school districts offering kindergarten is coded as the sum of districts in each of the following categories: $\mathrm{K}-6, \mathrm{~K}-8, \mathrm{~K}-9$, and $\mathrm{K}-12$. The rate of kindergarten availability is then the proportion of all primary school districts in the state that offer kindergarten, so defined, where primary school 
districts are those operating either kindergarten or first grade. In years where grade span data is not available $(1971 / 72,1974 / 75$, and 1984/85), the rate of kindergarten availability is estimated through linear interpolation, which should tend to smooth over trend breaks in state-level series.

Starting in 1967/68, comparable data on enrollment are supposedly given in the prior year's version of the publication from which I draw enrollment aggregates (see above). However, instructions for completing the relevant survey form (Appendix A in published versions of the data from 1971/72 forward) indicate that a state is to update its grade span (but not necessarily project its enrollment) for the current (reported) academic year. It is unclear whether all districts updated their grade span in this way, or if the updated data was indeed reflected in the microdata. As a result of this uncertainty, I lag the kindergarten availability series by one year. Thus, the series discussed above spans the academic years 1966/67 through 1989/90.

\section{References}

Anderson, Patricia M. and Philip B. Levine. 1999. “Child Care and Mother's Employment Decisions.” NBER Working Paper 7058. Cambridge, MA: National Bureau of Economic Research.

Angrist, Joshua D. and Alan B. Krueger. 1991. "Does Compulsory School Attendance Affect Schooling and Earnings?" Quarterly Journal of Economics 106(4): 979-1014.

Baker, Michael, Jonathan Gruber, and Kevin Milligan. 2005. 'Universal Child care, Maternal Labor Supply and Family Well-Being.” NBER Working Paper 11832. Cambridge, MA: National Bureau of Economic Research.

Barnett, W. Steven. 1995. "Long-Term Effects of Early Childhood Programs on Cognitive and School Outcomes." The Future of Children 5(3): 25-50. 
Berlinski, Samuel and Sebastian Galiani. 2005. "The Effect of a Large Expansion of Pre-Primary School Facilities on Preschool Attendance and Maternal Employment." Institute for Fiscal Studies Working Paper 04/30.

Bound, John and David A. Jaeger. 2000. "Do Compulsory School Attendance Laws Alone Explain the Association Between Quarter of Birth and Earnings?" In Research in Labor Economics, Vol. 19, ed. Solomon Polachek, 83-108. Amsterdam: Elsevier.

Bound, John, David Jaeger, and Regina Baker. 1995. "Problems with Instrumental Variables Estimation When the Correlation Between and Instruments and the Endogenous Explanatory Variable is Weak." Journal of the American Statistical Association 90(430): 443450.

Blau, David and Janet Currie. 2004. 'Preschool, Day Care, and After School Care: Who’s Minding the Kids?” NBER Working Paper 10670. Cambridge, MA: National Bureau of Economic Research.

Cascio, Elizabeth U. 2004. 'Schooling Attainment and the Introduction of Kindergartens into Public Schools.” Manuscript, University of California at Davis.

Cascio, Elizabeth U. and Ethan G. Lewis. 2006. "Schooling and the Armed Forces Qualifying Test: Evidence from School Entry Laws.” Forthcoming, Journal of Human Resources 41(2). Coelen, Craig, Frederic Glantz, and Daniel Colore. 1979. Day Care Centers in the U.S.: A National Profile, 1976-1977. Cambridge, MA: Abt Associates, Inc.

Cunha, Flavio, James J. Heckman, Lance Lochner, and Dimitriy V. Masterov. 2005.

“Interpreting the Evidence on Life Cycle Skill Formation.” IZA Discussion Paper 1675. Bonn: Institute for the Study of Labor.

Currie, Janet. 2001. "Early Childhood Education Programs." Journal of Economic Perspectives 15(2): 213-238. 
Gelbach, Jonah B. 1999. “How Large an Effect Do Child Care Costs Have on Single Mothers’ Labor Supply? Evidence Using Access to Free Public Schooling.” Manuscript, University of Maryland at College Park.

----. 2002. "Public Schooling for Young Children and Maternal Labor Supply." American Economic Review 92(1): 307-322.

Hausman, Jerry. 2001. "Mismeasured Variables in Econometric Analysis: Problems from the Right and Problems from the Left." Journal of Economic Perspectives 15(4): 57-68.

Karoly, Lynn A. and James H. Bigelow. 2005. The Economics of Investing in Universal Preschool Education in California. Santa Monica: RAND Corporation.

Karoly, Lynn A., Peter W. Greenwood, Susan S. Everingham, Jill Hoube, M. Rebecca Kilburn, C. Peter Rydell, Matthew Sanders, and James Chiesa. 1997. Investing in Our Children: What We Know and Don't Know About the Costs and Benefits of Early Childhood Interventions. Santa Monica: RAND Corporation.

Lueck, Marjorie, Ann C. Orr, and Martin O’Connell. 1982. Trends in Child care Arrangments of Working Mothers. Washington, D.C.: U.S. Government Printing Office.

Magnuson, Katherine A. and Jane Waldfogel. 2005. "Early Childhood Care and Education: Effects on Racial and Ethnic Gaps in School Readiness." The Future of Children 15(1): 169-196.

McCrary, Justin and Heather Royer. 2005. "The Effect of Maternal Education on Fertility and Infant Health: Evidence from School Entry Policies Using Exact Day of Birth,” Manuscript, University of Michigan.

Rosenbaum, Dan T. and Christopher Ruhm. 2005. "The Cost of Caring for Young Children." IZA Discussion Paper 1860. Bonn: Institute for the Study of Labor. 
Schlosser, Analía. 2005. "Public Preschool and the Labor Supply of Arab Mothers: Evidence from a Natural Experiment.” Manuscript, The Hebrew University of Jerusalem.

U.S. Department of Health, Education, and Welfare. 1968. Digest of Educational Statistics. Washington, D.C.: U.S. Government Printing Office.

Waite, Linda J. 1976. Daytime Care of Children: October 1974 and February 1975. Washington, D.C.: U.S. Government Printing Office. 
Table 1

Year of First State Funding for Kindergarten

Decade: Year States

Prior to $1960 \quad$ All states not listed below

The 1960s:

$\begin{array}{ll}1966 & \text { AK } \\ 1967 & \text { MD, MO } \\ 1968 & \text { DE, FL, NH, VA } \\ 1969 & \text { OK }\end{array}$

The 1970s:

$\begin{array}{ll}1971 & \text { AZ, WV } \\ 1973 & \text { AR, NC, OR, SC, TN, TX } \\ 1974 & \text { MT } \\ 1975 & \text { NM, ID } \\ 1977 & \text { AL, KY } \\ 1978 & \text { GA }\end{array}$

The 1980s:

1980 ND

1983 MS

Source: Cascio (2004) 
Table 2

Employment of Women with Five or Six Year Olds in Treated States, 1950-1990

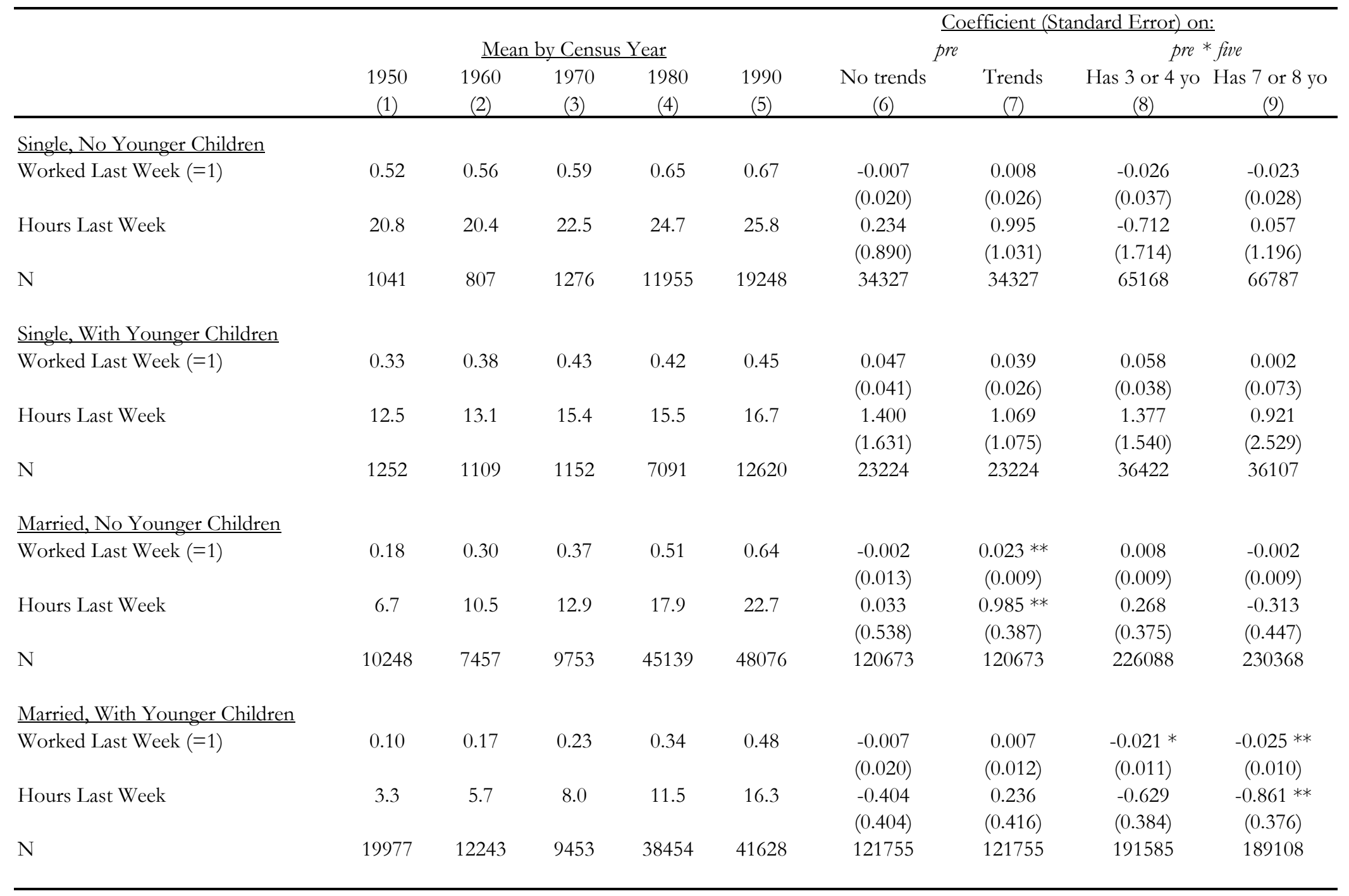

Notes: See text and Data Appendix for description of samples. All means and regressions are weighted by population weights, and standard errors are consistent for heteroskedasticity and error correlation within states over time. Each regression includes state fixed effects, year fixed effects, and share . The models in (7) also include quadratic state trends, and the models in (8) and (9) also include state * five fixed effects, year $*$ five fixed effects, direct effects of pre and five. The comparisons in (8) are mothers of three and four year olds and in (9) are the mothers of seven and eight year olds. $* * *, * *$, and $*$ denote statistically significant at the $1 \%, 5 \%$, and $10 \%$ levels, respectively. 
Table 3

Background Characteristics of Single Women with a Five or Six Year Old: Treated States, 1950-1990

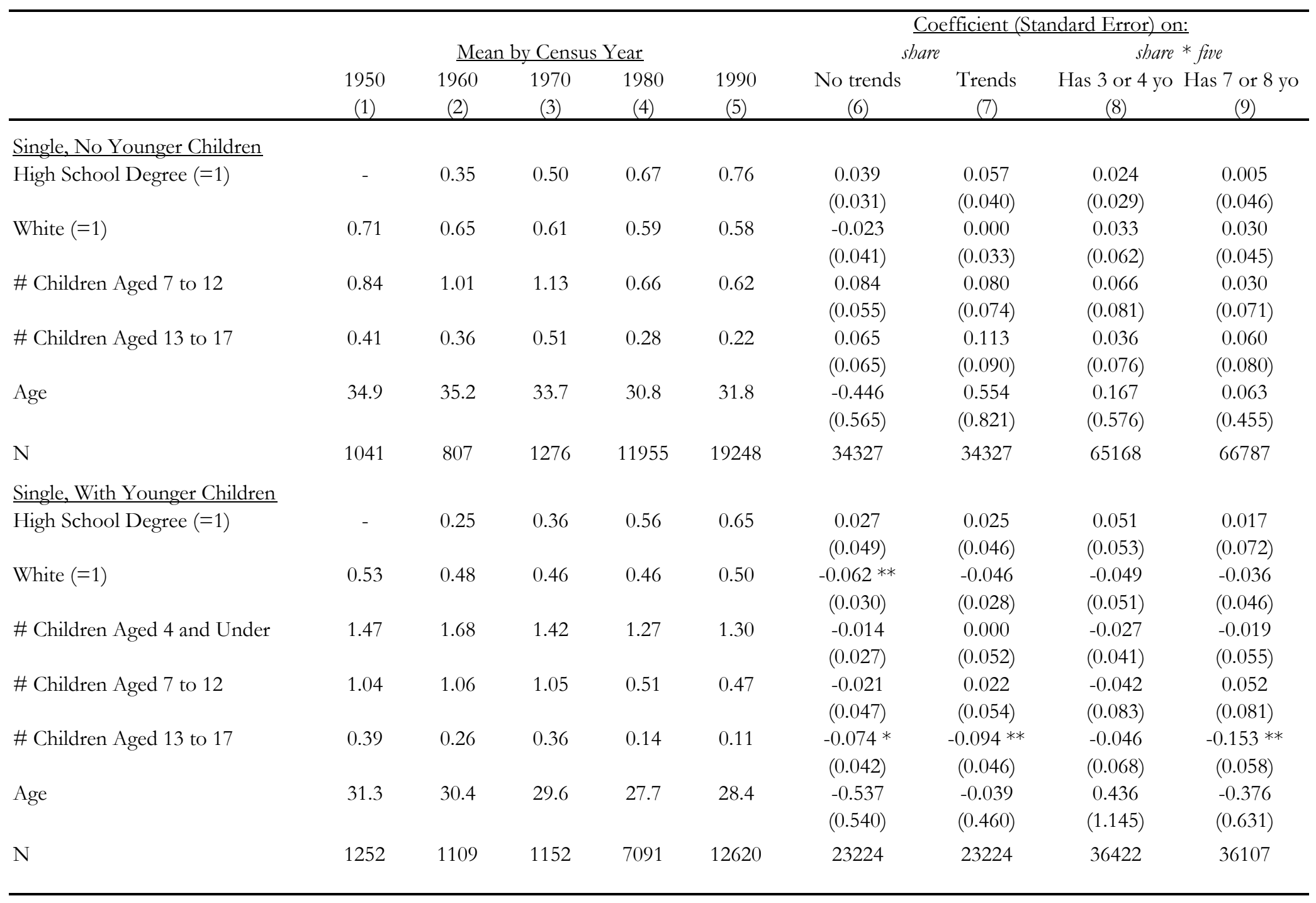

Notes: See text and Data Appendix for description of samples. All means and regressions are weighted by population weights, and standard errors are consistent for heteroskedasticity and error correlation within states over time. Each regression includes state fixed effects and year fixed effects. The models in (7) also include quadratic state trends, and the models in (8) and (9) also include state * five fixed effects, year* five fixed effects, direct effects of share and five. The comparisons in (8) are mothers of three and four year olds and in (9) are the mothers of seven and eight year olds. Models for high school degree only use data from 1960 - 1990.

$* * *, * *$, and $*$ denote statistically significant at the $1 \%, 5 \%$, and $10 \%$ levels, respectively. 
Table 4

Background Characteristics of Married Women with a Five or Six Year Old: Treated States, 1950-1990

\begin{tabular}{|c|c|c|c|c|c|c|c|c|c|}
\hline & \multirow{2}{*}{\multicolumn{5}{|c|}{ Mean by Census Year }} & \multicolumn{4}{|c|}{ Coefficient (Standard Error) on: } \\
\hline & & & & & & \multicolumn{2}{|c|}{ share } & \multicolumn{2}{|c|}{ share $*$ five } \\
\hline & $\begin{array}{c}1950 \\
(1) \\
\end{array}$ & $\begin{array}{c}1960 \\
(2) \\
\end{array}$ & $\begin{array}{c}1970 \\
(3)\end{array}$ & $\begin{array}{c}1980 \\
(4) \\
\end{array}$ & $\begin{array}{c}1990 \\
(5) \\
\end{array}$ & $\begin{array}{c}\text { No trends } \\
\text { (6) }\end{array}$ & $\begin{array}{l}\text { Trends } \\
(7)\end{array}$ & $\begin{array}{c}\text { Has } 3 \text { or } 4 \text { yo } \\
(8)\end{array}$ & $\begin{array}{c}\text { Has } 7 \text { or } 8 \text { yo } \\
(9)\end{array}$ \\
\hline \multicolumn{10}{|l|}{ Married, No Younger Children } \\
\hline High School Degree $(=1)$ & - & 0.52 & 0.61 & 0.75 & 0.85 & $\begin{array}{l}-0.025 \\
(0.019)\end{array}$ & $\begin{array}{c}-0.044 * * \\
(0.018)\end{array}$ & $\begin{array}{l}-0.012 \\
(0.017)\end{array}$ & $\begin{array}{c}-0.026 \text { ** } \\
(0.010)\end{array}$ \\
\hline White $(=1)$ & 0.89 & 0.90 & 0.89 & 0.85 & 0.83 & $\begin{array}{c}-0.037 * * \\
(0.018)\end{array}$ & $\begin{array}{l}-0.020 \\
(0.014)\end{array}$ & $\begin{array}{l}-0.011 \\
(0.013)\end{array}$ & $\begin{array}{l}-0.006 \\
(0.011)\end{array}$ \\
\hline \# Children Aged 7 to 12 & 0.91 & 1.05 & 1.18 & 0.82 & 0.80 & $\begin{array}{c}0.060 \\
(0.033)\end{array}$ & $\begin{array}{c}0.035 \\
(0.037)\end{array}$ & $\begin{array}{c}0.034 \\
(0.031)\end{array}$ & $\begin{array}{c}0.056 * * \\
(0.025)\end{array}$ \\
\hline \# Children Aged 13 to 17 & 0.45 & 0.37 & 0.50 & 0.32 & 0.26 & $\begin{array}{c}0.031 \\
(0.022)\end{array}$ & $\begin{array}{l}-0.028 \\
(0.024)\end{array}$ & $\begin{array}{l}-0.019 \\
(0.022)\end{array}$ & $\begin{array}{c}0.001 \\
(0.028)\end{array}$ \\
\hline Age & 34.7 & 34.9 & 33.9 & 32.5 & 33.9 & $\begin{array}{c}0.095 \\
(0.165)\end{array}$ & $\begin{array}{l}-0.216 \\
(0.218)\end{array}$ & $\begin{array}{l}-0.154 \\
(0.351)\end{array}$ & $\begin{array}{l}-0.227 \\
(0.275)\end{array}$ \\
\hline $\mathrm{N}$ & 10248 & 7457 & 9753 & 45139 & 48076 & 120673 & 120673 & 226088 & 230368 \\
\hline \multicolumn{10}{|l|}{ Married, With Younger Children } \\
\hline High School Degree $(=1)$ & - & 0.45 & 0.57 & 0.74 & 0.83 & $\begin{array}{l}-0.006 \\
(0.014)\end{array}$ & $\begin{array}{c}0.017 \\
(0.013)\end{array}$ & $\begin{array}{c}0.005 \\
(0.021)\end{array}$ & $\begin{array}{c}0.018 \\
(0.026)\end{array}$ \\
\hline White $(=1)$ & 0.80 & 0.81 & 0.84 & 0.82 & 0.84 & $\begin{array}{c}-0.073 * * * \\
(0.022)\end{array}$ & $\begin{array}{c}-0.073 * * \\
(0.014)\end{array}$ & $\begin{array}{l}-0.009 \\
(0.010)\end{array}$ & $\begin{array}{c}-0.031 \text { ** } \\
(0.012)\end{array}$ \\
\hline \# Children Aged 4 and Under & 1.55 & 1.61 & 1.35 & 1.24 & 1.22 & $\begin{array}{c}0.065 \text { *** } \\
(0.021)\end{array}$ & $\begin{array}{c}0.025 \\
(0.028)\end{array}$ & $\begin{array}{c}0.049 \\
(0.030)\end{array}$ & $\begin{array}{c}0.038 \\
(0.024)\end{array}$ \\
\hline \# Children Aged 7 to 12 & 1.03 & 0.98 & 0.85 & 0.43 & 0.40 & $\begin{array}{c}0.079 \\
(0.040)\end{array}$ & $\begin{array}{l}-0.014 \\
(0.037)\end{array}$ & $\begin{array}{c}0.022 \\
(0.036)\end{array}$ & $\begin{array}{c}0.057^{* *} \\
(0.027)\end{array}$ \\
\hline \# Children Aged 13 to 17 & 0.39 & 0.23 & 0.23 & 0.09 & 0.08 & $\begin{array}{c}0.014 \\
(0.020)\end{array}$ & $\begin{array}{l}-0.027 \\
(0.024)\end{array}$ & $\begin{array}{l}-0.008 \\
(0.020)\end{array}$ & $\begin{array}{l}-0.057 \\
(0.042)\end{array}$ \\
\hline Age & 31.2 & 30.4 & 29.5 & 29.0 & 30.6 & $\begin{array}{l}-0.273 \\
(0.290)\end{array}$ & $\begin{array}{l}-0.475 \\
(0.314)\end{array}$ & $\begin{array}{c}0.085 \\
(0.262)\end{array}$ & $\begin{array}{l}-0.413 \\
(0.456)\end{array}$ \\
\hline $\mathrm{N}$ & 19977 & 12243 & 9453 & 38454 & 41628 & 121755 & 121755 & 191585 & 189108 \\
\hline
\end{tabular}

Notes: See Table 3.

$* * *, * *$, and $*$ denote statistically significant at the $1 \%, 5 \%$, and $10 \%$ levels, respectively. 
Table 5

Kindergarten Availability and Maternal Employment: Single Women with a Five or Six Year Old, 1950-1990

\begin{tabular}{|c|c|c|c|c|c|c|c|}
\hline \multirow[b]{3}{*}{$\underline{\text { Dependent Variable }}$} & \multirow{3}{*}{$\begin{array}{c}\text { Pre-initiative } \\
\text { mean } \\
\text { (1) }\end{array}$} & \multirow{2}{*}{\multicolumn{2}{|c|}{$\begin{array}{c}\text { Coefficient (Standard Error) } \\
\text { on share }\end{array}$}} & \multicolumn{4}{|c|}{ Coefficient (Standard Error) on share $*$ five } \\
\hline & & & & \multicolumn{2}{|c|}{$\begin{array}{l}\text { Comparison Group: } \\
\text { Has } 3 \text { or } 4 \text { Year Old }\end{array}$} & \multicolumn{2}{|c|}{$\begin{array}{l}\text { Comparison Group: } \\
\text { Has } 7 \text { or } 8 \text { Year Old }\end{array}$} \\
\hline & & (2) & (3) & (4) & (5) & (6) & (7) \\
\hline & \multicolumn{7}{|c|}{ Has 5 or 6 Year Old, No Younger Children } \\
\hline Worked Last Week $(=1)$ & 0.575 & $\begin{array}{c}0.062 \\
(0.050)\end{array}$ & $\begin{array}{c}0.081 \\
(0.058)\end{array}$ & $\begin{array}{c}0.085 \\
(0.052)\end{array}$ & $\begin{array}{c}0.072 \\
(0.050)\end{array}$ & $\begin{array}{c}0.076 \\
(0.043)\end{array}$ & $\begin{array}{r}0.073 \\
(0.044)\end{array}$ \\
\hline Hours Last Week & 21.82 & $\begin{array}{c}2.263 \\
(2.086)\end{array}$ & $\begin{array}{l}3.230 \\
(2.235)\end{array}$ & $\begin{array}{l}2.560 \\
(2.129)\end{array}$ & $\begin{array}{c}1.965 \\
(2.008)\end{array}$ & $\begin{array}{c}3.288 \\
(1.536)\end{array}$ & $\begin{array}{l}3.133 \\
(1.541)\end{array}$ \\
\hline \multirow[t]{2}{*}{$\mathrm{N}$} & & 34327 & 34327 & 65168 & 65168 & 66787 & 66787 \\
\hline & \multicolumn{7}{|c|}{ Has 5 or 6 Year Old and Younger Children } \\
\hline Worked Last Week (=1) & 0.430 & $\begin{array}{l}-0.016 \\
(0.027)\end{array}$ & $\begin{array}{l}-0.051 \\
(0.056)\end{array}$ & $\begin{array}{l}-0.057 \\
(0.039)\end{array}$ & $\begin{array}{l}-0.045 \\
(0.035)\end{array}$ & $\begin{array}{l}-0.026 \\
(0.045)\end{array}$ & $\begin{array}{l}-0.026 \\
(0.044)\end{array}$ \\
\hline Hours Last Week & 15.29 & $\begin{array}{l}-0.541 \\
(1.099)\end{array}$ & $\begin{array}{l}-2.333 \\
(2.219)\end{array}$ & $\begin{array}{l}-1.425 \\
(1.529)\end{array}$ & $\begin{array}{l}-1.117 \\
(1.458)\end{array}$ & $\begin{array}{l}-0.319 \\
(1.748)\end{array}$ & $\begin{array}{l}-0.440 \\
(1.735)\end{array}$ \\
\hline $\mathrm{N}$ & & 23224 & 23224 & 36422 & 36422 & 36107 & 36107 \\
\hline $\begin{array}{l}\text { Controls: } \\
\text { State Trends (Quadratic) }\end{array}$ & & & $\mathrm{X}$ & & & & \\
\hline State $*$ five Fixed Effects & & & & $\mathrm{x}$ & $\mathrm{x}$ & $\mathrm{X}$ & $\mathrm{x}$ \\
\hline Year* five Fixed Effects & & & & $\mathrm{X}$ & $\mathrm{X}$ & $\mathrm{X}$ & $\mathrm{x}$ \\
\hline State * Year Fixed Effects & & & & & $\mathrm{X}$ & & $\mathrm{X}$ \\
\hline
\end{tabular}

Notes: See text and Data Appendix for description of samples. Pre-initiative means are calculated using data from the Census year prior to the initiative. Each entry in columns (2) through (7) represents a coefficient from a different regression. All regressions include state fixed effects, year fixed effects, and a vector of maternal background characteristics (indicator variables for black and other race, a quadratic in maternal age, and quadratics in the number of own children between the ages of 0 and 4 , age 5 , age 6 , between the ages of 7 and 12, and between the ages of 13 and 17). All means and regressions are weighted by population weights, and standard errors consistent for heteroskedasticity and error correlation within states over time. 
Table 6

Kindergarten Availability and School Enrollment: Five and Six Year Olds with Single Mothers, 1960-1990

\begin{tabular}{|c|c|c|c|c|c|}
\hline \multirow[b]{2}{*}{ Dependent Variable } & \multirow{2}{*}{$\begin{array}{c}\text { Pre-initiative } \\
\text { mean } \\
(1)\end{array}$} & \multicolumn{2}{|c|}{$\begin{array}{c}\text { Coefficient (Standard Error) on } \\
\text { share }\end{array}$} & \multicolumn{2}{|c|}{$\begin{array}{c}\text { Coefficient (Standard Error) on } \\
\text { share } * \text { five } \uparrow\end{array}$} \\
\hline & & $(2)$ & (3) & $(4)$ & $(5)$ \\
\hline & \multicolumn{5}{|c|}{$\underline{5 \text { or } 6 \text { Years Old, No Younger Siblings }}$} \\
\hline Public School (=1) & 0.489 & $\begin{array}{c}0.239 \\
(0.048)\end{array}$ & $\begin{array}{c}0.189 \\
(0.037)\end{array}$ & $\begin{array}{c}0.241 \\
(0.055)\end{array}$ & $\begin{array}{c}0.238 \\
(0.056)\end{array}$ \\
\hline Private School $(=1)$ & 0.115 & $\begin{array}{l}-0.095 \\
(0.022)\end{array}$ & $\begin{array}{l}-0.096 \\
(0.020)\end{array}$ & $\begin{array}{l}-0.100 \\
(0.025)\end{array}$ & $\begin{array}{l}-0.102 \\
(0.024)\end{array}$ \\
\hline \multirow[t]{2}{*}{$\mathrm{N}$} & & 35322 & 35322 & 68827 & 68827 \\
\hline & \multicolumn{5}{|c|}{$\underline{5 \text { or } 6 \text { Years Old, With Younger Siblings }}$} \\
\hline Public School (=1) & 0.452 & $\begin{array}{c}0.152 \\
(0.038)\end{array}$ & $\begin{array}{c}0.117 \\
(0.037)\end{array}$ & $\begin{array}{c}0.122 \\
(0.031)\end{array}$ & $\begin{array}{c}0.108 \\
(0.032)\end{array}$ \\
\hline Private School $(=1)$ & 0.062 & $\begin{array}{l}-0.005 \\
(0.023)\end{array}$ & $\begin{array}{l}-0.001 \\
(0.026)\end{array}$ & $\begin{array}{c}0.015 \\
(0.025)\end{array}$ & $\begin{array}{c}0.014 \\
(0.025)\end{array}$ \\
\hline $\mathrm{N}$ & & 23520 & 23520 & 36755 & 36755 \\
\hline Controls: & & & & & \\
\hline State Trends (Linear) & & & $\mathrm{X}$ & & \\
\hline State * five Fixed Effects & & & & $\mathrm{X}$ & $\mathrm{X}$ \\
\hline Year * five Fixed Effects & & & & $\mathrm{X}$ & $\mathrm{X}$ \\
\hline State $*$ Year Fixed Effects & & & & & $\mathrm{X}$ \\
\hline
\end{tabular}

Notes: See text and Data Appendix for description of samples. Pre-initiative means are calculated using data from the Census year prior to the initiative. Each entry in columns (2) through (7) represents a coefficient from a different regression. All regressions include state fixed effects, year fixed effects, and a vector of maternal background characteristics (see Table 5). All means and regressions are weighted by population weights, and standard errors are consistent for heteroskedasticity and error correlation within state over time. † Comparison group consists of 7 and 8 year olds with no 5 or 6 year old siblings. 
Table 7

Kindergarten Availability, School Enrollment, and Maternal Employment:

Single Women without a Five or Six Year Old, 1950-1990

\begin{tabular}{|c|c|c|c|c|c|c|}
\hline \multirow[b]{3}{*}{ Dependent Variable } & \multicolumn{3}{|c|}{ Mothers of 3 and 4 Year Olds } & \multicolumn{3}{|c|}{ Mothers of 7 and 8 Year Olds } \\
\hline & \multirow{2}{*}{$\begin{array}{c}\text { Pre-initiative } \\
\text { mean } \\
(1) \\
\end{array}$} & \multicolumn{2}{|c|}{$\begin{array}{c}\text { Coefficient (Standard Error) } \\
\text { on share }\end{array}$} & \multirow{2}{*}{$\begin{array}{c}\text { Pre-initiative } \\
\text { mean } \\
(4) \\
\end{array}$} & \multicolumn{2}{|c|}{$\begin{array}{c}\text { Coefficient (Standard Error) } \\
\text { on share }\end{array}$} \\
\hline & & $(2)$ & (3) & & $(5)$ & $(6)$ \\
\hline & \multicolumn{6}{|c|}{ Without Younger Children } \\
\hline Worked Last Week (=1) & 0.565 & $\begin{array}{l}-0.024 \\
(0.023)\end{array}$ & $\begin{array}{c}0.015 \\
(0.046)\end{array}$ & 0.632 & $\begin{array}{l}-0.015 \\
(0.028)\end{array}$ & $\begin{array}{c}0.021 \\
(0.028)\end{array}$ \\
\hline Hours Last Week & 21.48 & $\begin{array}{l}-0.297 \\
(0.882)\end{array}$ & $\begin{array}{c}1.332 \\
(2.104)\end{array}$ & 23.72 & $\begin{array}{l}-1.025 \\
(1.406)\end{array}$ & $\begin{array}{c}0.879 \\
(1.130)\end{array}$ \\
\hline $\mathrm{N}$ & & 30841 & 30841 & & 32460 & 32460 \\
\hline Child in Public School $(=1)$ & - & - & - & 0.912 & $\begin{array}{l}-0.002 \\
(0.012)\end{array}$ & $\begin{array}{c}0.001 \\
(0.016)\end{array}$ \\
\hline \multirow[t]{2}{*}{$\mathrm{N}$} & & - & - & & 33505 & 33505 \\
\hline & \multicolumn{6}{|c|}{$\underline{\text { With Younger Children }}$} \\
\hline Worked Last Week $(=1)$ & 0.360 & $\begin{array}{c}0.041 \\
(0.042)\end{array}$ & $\begin{array}{c}0.080 \\
(0.068)\end{array}$ & 0.453 & $\begin{array}{c}0.010 \\
(0.041)\end{array}$ & $\begin{array}{c}0.006 \\
(0.055)\end{array}$ \\
\hline Hours Last Week & 13.53 & $\begin{array}{c}0.884 \\
(1.789)\end{array}$ & $\begin{array}{c}2.005 \\
(2.915)\end{array}$ & 16.33 & $\begin{array}{l}-0.222 \\
(1.617)\end{array}$ & $\begin{array}{c}0.949 \\
(2.111)\end{array}$ \\
\hline $\mathrm{N}$ & & 13198 & 13198 & & 12883 & 12883 \\
\hline Child in Public School $(=1)$ & - & - & - & 0.924 & $\begin{array}{c}0.030 \\
(0.022)\end{array}$ & $\begin{array}{c}0.030 \\
(0.023)\end{array}$ \\
\hline $\mathrm{N}$ & & - & - & & 13235 & 13235 \\
\hline $\begin{array}{l}\text { Controls: } \\
\text { Smooth State Trends }\end{array}$ & & & $\mathrm{X}$ & & & $\mathrm{X}$ \\
\hline
\end{tabular}

Notes: See text and Data Appendix for description of samples. Each entry in columns (2), (3), (5), and (6) represents a coefficient from a different regression. All regressions include state fixed effects, year fixed effects, and a vector of maternal background characteristics (see Table 5). Where noted, employment regressions include quadratic state trends, while enrollment regressions include linear state trends. Enrollment regressions use data from 1960 to 1990 only, and the child is the unit of observation. All means and regressions are weighted by population weights, and standard errors consistent for heteroskedasticity and error correlation within state over time. 
Table 8

Kindergarten Availability and Maternal Employment: Married Women with a Five or Six Year Old, 1950-1990

\begin{tabular}{|c|c|c|c|c|c|c|c|}
\hline \multirow[b]{3}{*}{ Dependent Variable } & \multirow{3}{*}{$\begin{array}{c}\text { Pre-initiative } \\
\text { mean } \\
(1)\end{array}$} & \multirow{2}{*}{\multicolumn{2}{|c|}{$\begin{array}{c}\text { Coefficient (Standard Error) } \\
\text { on share }\end{array}$}} & \multicolumn{4}{|c|}{ Coefficient (Standard Error) on share $*$ five } \\
\hline & & & & \multicolumn{2}{|c|}{$\begin{array}{l}\text { Comparison Group: } \\
\text { Has } 3 \text { or } 4 \text { Year Old }\end{array}$} & \multicolumn{2}{|c|}{$\begin{array}{l}\text { Comparison Group: } \\
\text { Has } 7 \text { or } 8 \text { Year Old }\end{array}$} \\
\hline & & $(2)$ & (3) & $(4)$ & $(5)$ & $(6)$ & $(7)$ \\
\hline & \multicolumn{7}{|c|}{ Has 5 or 6 Year Old, No Younger Children } \\
\hline Worked Last Week (=1) & 0.366 & $\begin{array}{l}-0.029 \\
(0.017)\end{array}$ & $\begin{array}{c}0.006 \\
(0.022)\end{array}$ & $\begin{array}{c}0.003 \\
(0.013)\end{array}$ & $\begin{array}{c}0.008 \\
(0.013)\end{array}$ & $\begin{array}{l}-0.028 \\
(0.013)\end{array}$ & $\begin{array}{l}-0.025 \\
(0.013)\end{array}$ \\
\hline Hours Last Week & 12.73 & $\begin{array}{l}-1.245 \\
(0.740)\end{array}$ & $\begin{array}{c}0.296 \\
(0.878)\end{array}$ & $\begin{array}{c}0.092 \\
(0.489)\end{array}$ & $\begin{array}{c}0.286 \\
(0.484)\end{array}$ & $\begin{array}{l}-0.925 \\
(0.576)\end{array}$ & $\begin{array}{l}-0.809 \\
(0.581)\end{array}$ \\
\hline \multirow[t]{2}{*}{$\mathrm{N}$} & & 120673 & 120673 & 226088 & 226088 & 230368 & 230368 \\
\hline & \multicolumn{7}{|c|}{ Has 5 or 6 Year Old and Younger Children } \\
\hline Worked Last Week (=1) & 0.214 & $\begin{array}{l}-0.021 \\
(0.011)\end{array}$ & $\begin{array}{l}-0.003 \\
(0.012)\end{array}$ & $\begin{array}{c}0.017 \\
(0.014)\end{array}$ & $\begin{array}{c}0.016 \\
(0.014)\end{array}$ & $\begin{array}{c}0.017 \\
(0.018)\end{array}$ & $\begin{array}{c}0.017 \\
(0.016)\end{array}$ \\
\hline Hours Last Week & 7.37 & $\begin{array}{l}-0.981 \\
(0.345)\end{array}$ & $\begin{array}{l}-0.036 \\
(0.426)\end{array}$ & $\begin{array}{c}0.319 \\
(0.506)\end{array}$ & $\begin{array}{c}0.310 \\
(0.494)\end{array}$ & $\begin{array}{c}0.584 \\
(0.597)\end{array}$ & $\begin{array}{c}0.622 \\
(0.559)\end{array}$ \\
\hline $\mathrm{N}$ & & 121755 & 121755 & 191585 & 191585 & 189108 & 189108 \\
\hline $\begin{array}{l}\text { Controls: } \\
\text { State Trends (Ouadratic) }\end{array}$ & & & X & & & & \\
\hline State $*$ five Fixed Effects & & & & $\mathrm{X}$ & $\mathrm{X}$ & $\mathrm{X}$ & $\mathrm{X}$ \\
\hline Year* five Fixed Effects & & & & $\mathrm{X}$ & $\mathrm{X}$ & $\mathrm{X}$ & $\mathrm{X}$ \\
\hline State $*$ Year Fixed Effects & & & & & $\mathrm{X}$ & & $\mathrm{X}$ \\
\hline
\end{tabular}

Notes: See Table 5. 
Table 9

Kindergarten Availability and School Enrollment: Five and Six Year Olds with Married Mothers, 1960-1990

\begin{tabular}{|c|c|c|c|c|c|}
\hline \multirow[b]{2}{*}{$\underline{\text { Dependent Variable }}$} & \multirow{2}{*}{$\begin{array}{l}\text { Pre-initiative } \\
\text { mean } \\
(1) \\
\end{array}$} & \multicolumn{2}{|c|}{$\begin{array}{c}\text { Coefficient (Standard Error) on } \\
\text { share }\end{array}$} & \multicolumn{2}{|c|}{$\begin{array}{c}\text { Coefficient (Standard Error) on } \\
\text { share } * \text { five } †\end{array}$} \\
\hline & & (2) & (3) & (4) & (5) \\
\hline & \multicolumn{5}{|c|}{$\underline{5 \text { or } 6}$ Years Old, No Younger Siblings } \\
\hline Public School $(=1)$ & 0.437 & $\begin{array}{c}0.262 \\
(0.024)\end{array}$ & $\begin{array}{c}0.233 \\
(0.024)\end{array}$ & $\begin{array}{c}0.244 \\
(0.021)\end{array}$ & $\begin{array}{c}0.242 \\
(0.021)\end{array}$ \\
\hline Private School $(=1)$ & 0.149 & $\begin{array}{l}-0.112 \\
(0.020)\end{array}$ & $\begin{array}{l}-0.107 \\
(0.020)\end{array}$ & $\begin{array}{l}-0.100 \\
(0.016)\end{array}$ & $\begin{array}{l}-0.100 \\
(0.016)\end{array}$ \\
\hline $\mathrm{N}$ & & 116891 & 116891 & 225028 & 225028 \\
\hline & \multicolumn{5}{|c|}{$\underline{5 \text { or } 6 \text { Years Old, With Younger Siblings }}$} \\
\hline Public School $(=1)$ & 0.409 & $\begin{array}{c}0.282 \\
(0.031)\end{array}$ & $\begin{array}{c}0.264 \\
(0.031)\end{array}$ & $\begin{array}{c}0.257 \\
(0.038)\end{array}$ & $\begin{array}{c}0.257 \\
(0.039)\end{array}$ \\
\hline Private School $(=1)$ & 0.130 & $\begin{array}{l}-0.108 \\
(0.017)\end{array}$ & $\begin{array}{l}-0.102 \\
(0.018)\end{array}$ & $\begin{array}{l}-0.093 \\
(0.024)\end{array}$ & $\begin{array}{l}-0.094 \\
(0.023)\end{array}$ \\
\hline $\mathrm{N}$ & & 107394 & 107394 & 169514 & 169514 \\
\hline $\begin{array}{l}\text { Controls: } \\
\text { State Trends (Linear) }\end{array}$ & & & $X$ & & \\
\hline $\begin{array}{l}\text { State * five Fixed Effects } \\
\text { Year * five Fixed Effects } \\
\text { State } * \text { Year Fixed Effects }\end{array}$ & & & $X$ & $\begin{array}{l}\mathrm{X} \\
\mathrm{X}\end{array}$ & $\begin{array}{l}X \\
X \\
X\end{array}$ \\
\hline
\end{tabular}

Notes: See Table 6.

† Comparison group consists of 7 and 8 year olds with no 5 or 6 year old siblings. 
Table 10

Kindergarten Availability, School Enrollment, and Maternal Employment:

Married Women without a Five or Six Year Old, 1950-1990

\begin{tabular}{|c|c|c|c|c|c|c|}
\hline \multirow[b]{3}{*}{ Dependent Variable } & \multicolumn{3}{|c|}{ Mothers of 3 and 4 Year Olds } & \multicolumn{3}{|c|}{ Mothers of 7 and 8 Year Olds } \\
\hline & \multirow{2}{*}{$\begin{array}{c}\text { Pre-initiative } \\
\text { mean } \\
(1)\end{array}$} & \multicolumn{2}{|c|}{$\begin{array}{c}\text { Coefficient (Standard Error) } \\
\text { on share }\end{array}$} & \multirow{2}{*}{$\begin{array}{c}\text { Pre-initiative } \\
\text { mean } \\
(4)\end{array}$} & \multicolumn{2}{|c|}{$\begin{array}{c}\text { Coefficient (Standard Error) } \\
\text { on share }\end{array}$} \\
\hline & & (2) & (3) & & $(5)$ & (6) \\
\hline & \multicolumn{6}{|c|}{ Without Younger Children } \\
\hline Worked Last Week $(=1)$ & 0.337 & $\begin{array}{l}-0.032 \\
(0.020)\end{array}$ & $\begin{array}{l}-0.021 \\
(0.024)\end{array}$ & 0.400 & $\begin{array}{l}-0.001 \\
(0.016)\end{array}$ & $\begin{array}{c}0.019 \\
(0.018)\end{array}$ \\
\hline Hours Last Week & 11.92 & $\begin{array}{l}-1.337 \\
(0.724)\end{array}$ & $\begin{array}{l}-0.991 \\
(0.832)\end{array}$ & 14.11 & $\begin{array}{l}-0.320 \\
(0.625)\end{array}$ & $\begin{array}{c}0.371 \\
(0.749)\end{array}$ \\
\hline $\mathrm{N}$ & & 105415 & 105415 & & 109695 & 109695 \\
\hline Child in Public School $(=1)$ & - & - & - & 0.907 & $\begin{array}{c}0.018 \\
(0.010)\end{array}$ & $\begin{array}{c}0.019 \\
(0.010)\end{array}$ \\
\hline \multirow[t]{2}{*}{$\mathrm{N}$} & & - & - & & 108137 & 108137 \\
\hline & \multicolumn{6}{|c|}{$\underline{\text { With Younger Children }}$} \\
\hline Worked Last Week $(=1)$ & 0.195 & $\begin{array}{l}-0.038 \\
(0.014)\end{array}$ & $\begin{array}{l}-0.023 \\
(0.022)\end{array}$ & 0.252 & $\begin{array}{l}-0.039 \\
(0.019)\end{array}$ & $\begin{array}{l}-0.023 \\
(0.019)\end{array}$ \\
\hline Hours Last Week & 6.67 & $\begin{array}{l}-1.301 \\
(0.501)\end{array}$ & $\begin{array}{l}-0.663 \\
(0.829)\end{array}$ & 8.54 & $\begin{array}{l}-1.565 \\
(0.634)\end{array}$ & $\begin{array}{l}-0.521 \\
(0.716)\end{array}$ \\
\hline $\mathrm{N}$ & & 69830 & 69830 & & 67353 & 67353 \\
\hline Child in Public School $(=1)$ & - & - & - & 0.888 & $\begin{array}{c}0.025 \\
(0.018)\end{array}$ & $\begin{array}{c}0.026 \\
(0.015)\end{array}$ \\
\hline $\mathrm{N}$ & & - & - & & 62120 & 62120 \\
\hline Controls: & & & & & & \\
\hline Smooth State Trends & & & $\mathrm{X}$ & & & $\mathrm{X}$ \\
\hline
\end{tabular}

Notes: See Table 7 


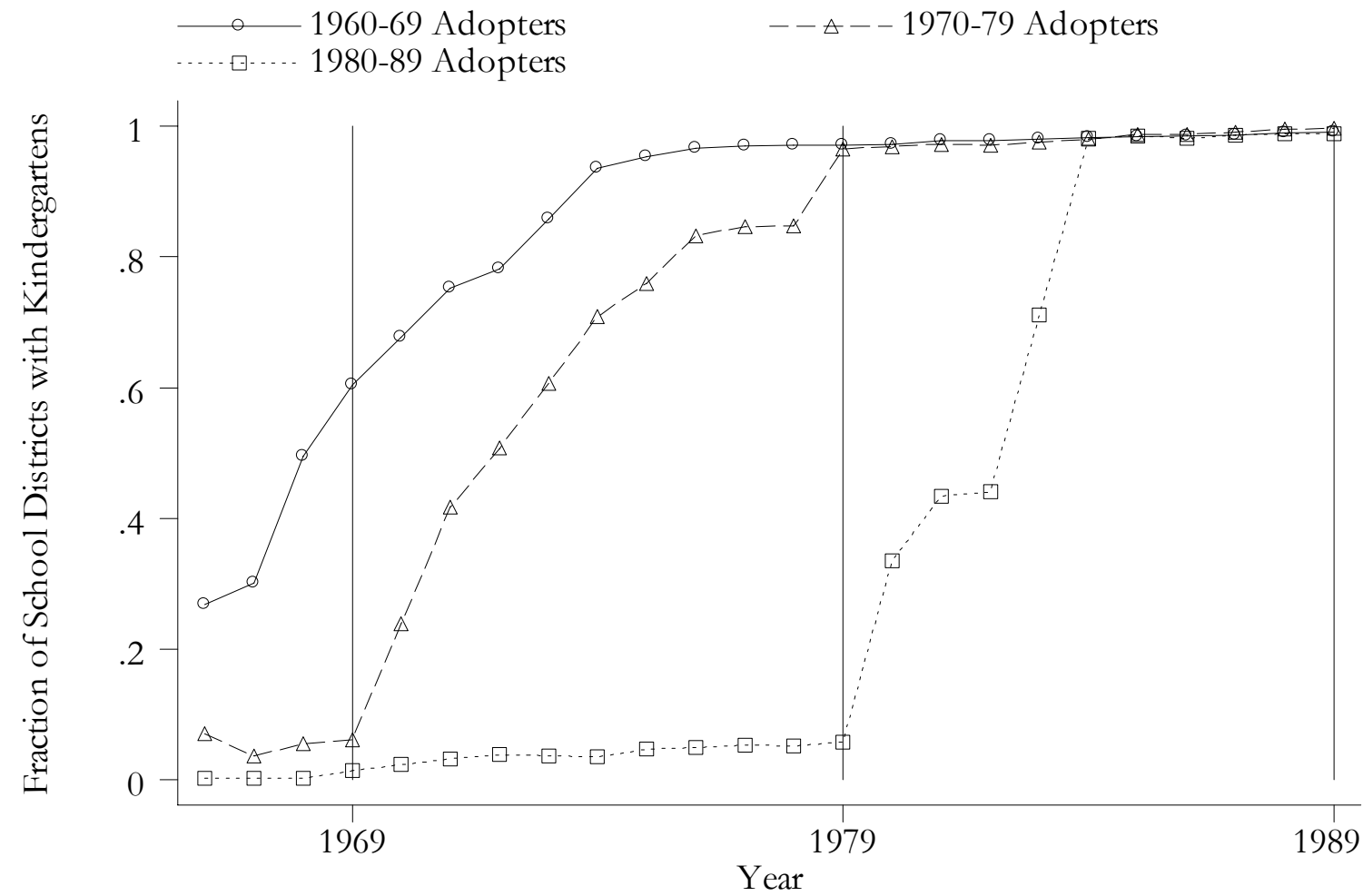

\section{Figure 1}

Kindergarten Supply by Year and Decade of First State Funding

Sources: See Data Appendix.

Notes: The underlying unit is the state-year fraction of primary school districts that offer

kindergarten programs. Annual averages are calculated weighting by current first grade enrollment. 
$\longrightarrow$ - 1960-69 Adopters - - - 1970-79 Adopters - - - - 1980-89 Adopters

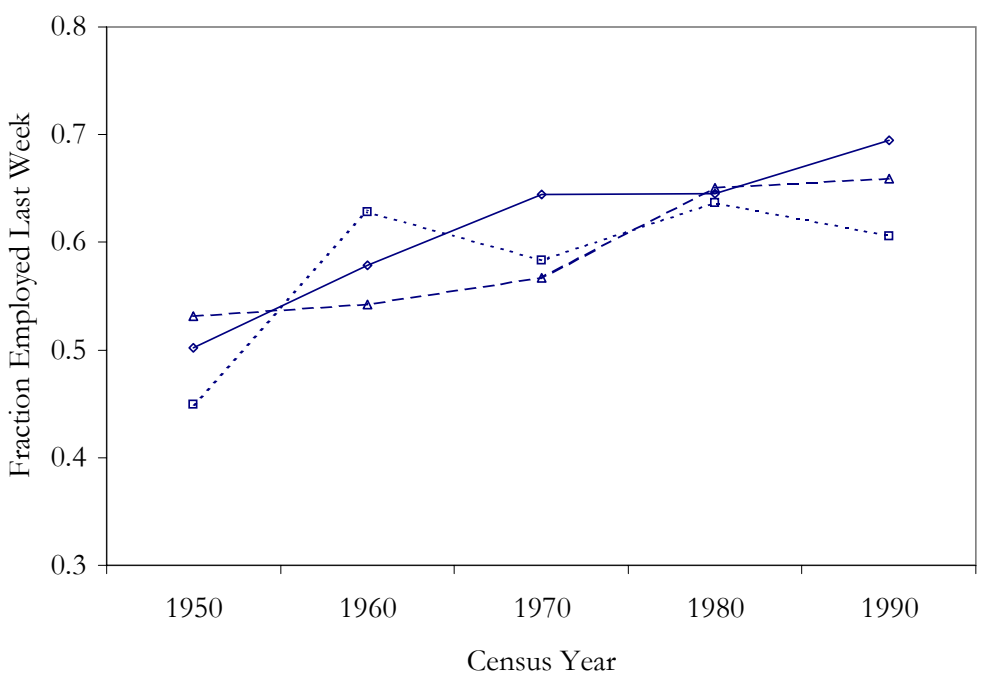

A. Employment of Treatment Group: Has 5 or 6 Year Old

๑ 1960-69 Adopters $-₫-1970-79$ Adopters $\cdots$ a $\cdots$ 1980-89 Adopters

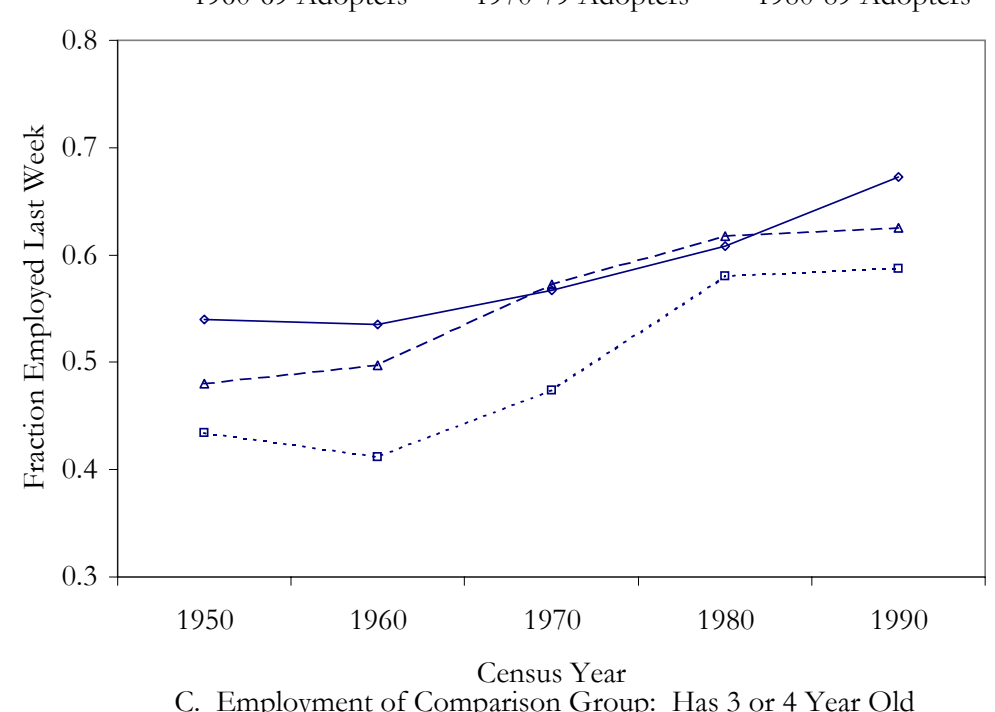

C. Employment of Comparison Group: Has 3 or 4 Year Old

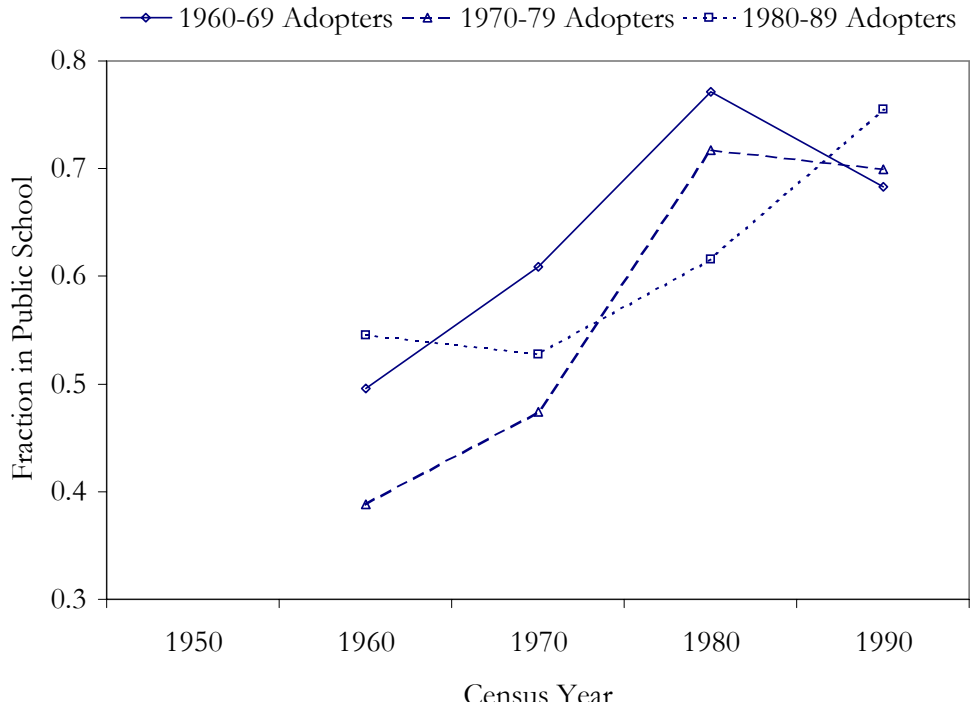

B. Enrollment of Treatment Group: 5 and 6 Year Olds

$\rightarrow$ 1960-69 Adopters - $₫-1970-79$ Adopters $\cdots$ - $\cdots 1980-89$ Adopters

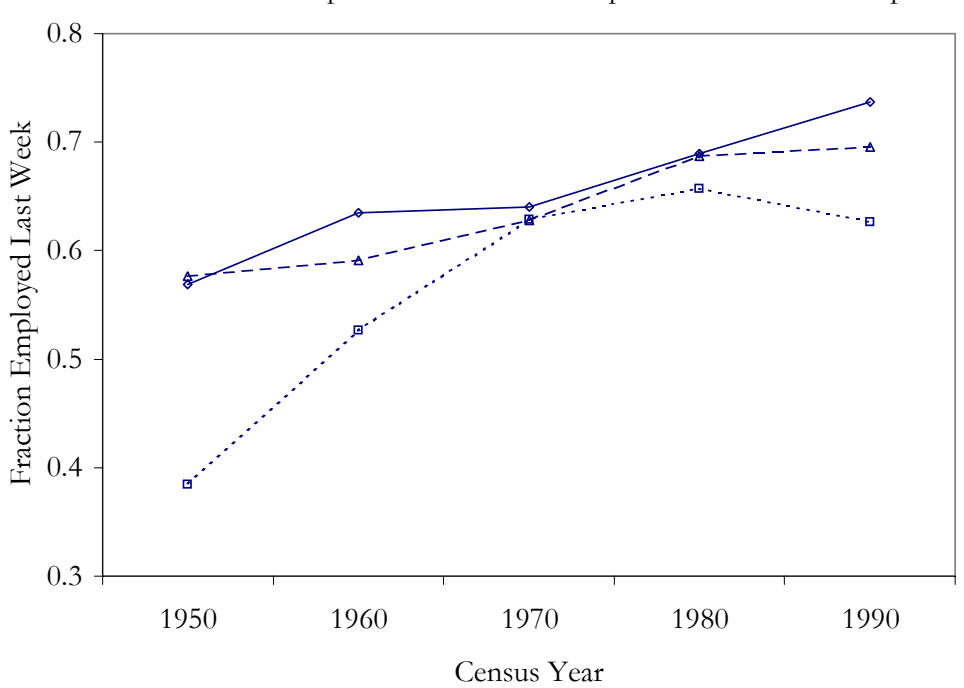

D. Employment of Comparison Group: Has 7 or 8 Year Old

\section{Figure 2}

Employment and Child Enrollment: Single Mothers of Five and Six Year Olds with No Younger Children 


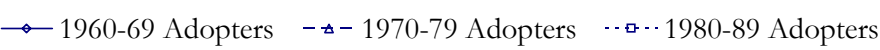

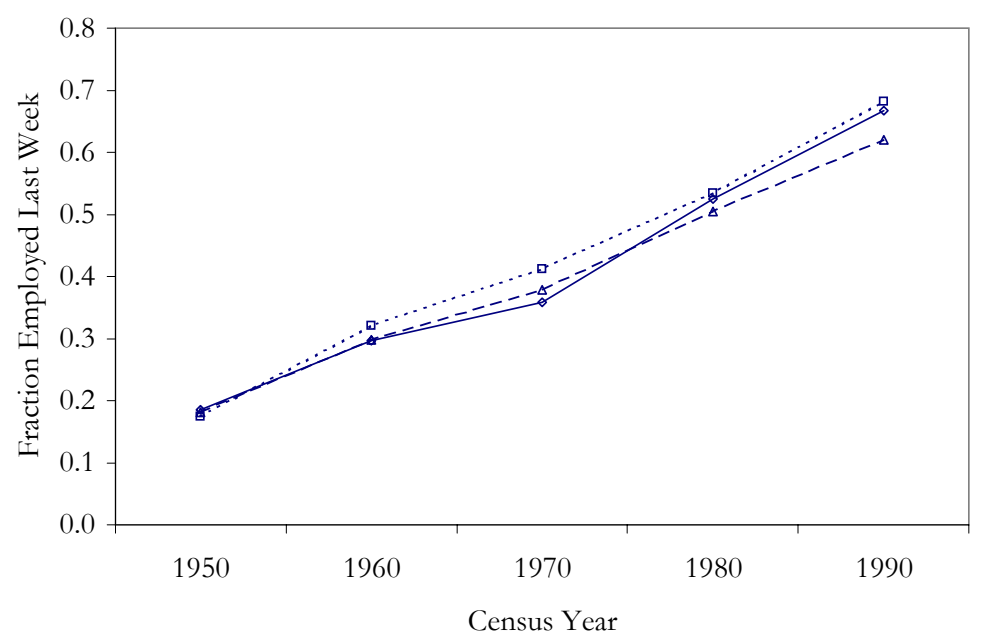

A. Employment of Treatment Group: Has 5 or 6 Year Old

$\rightarrow$ 1960-69 Adopters - - - 1970-79 Adopters … - 1980-89 Adopters

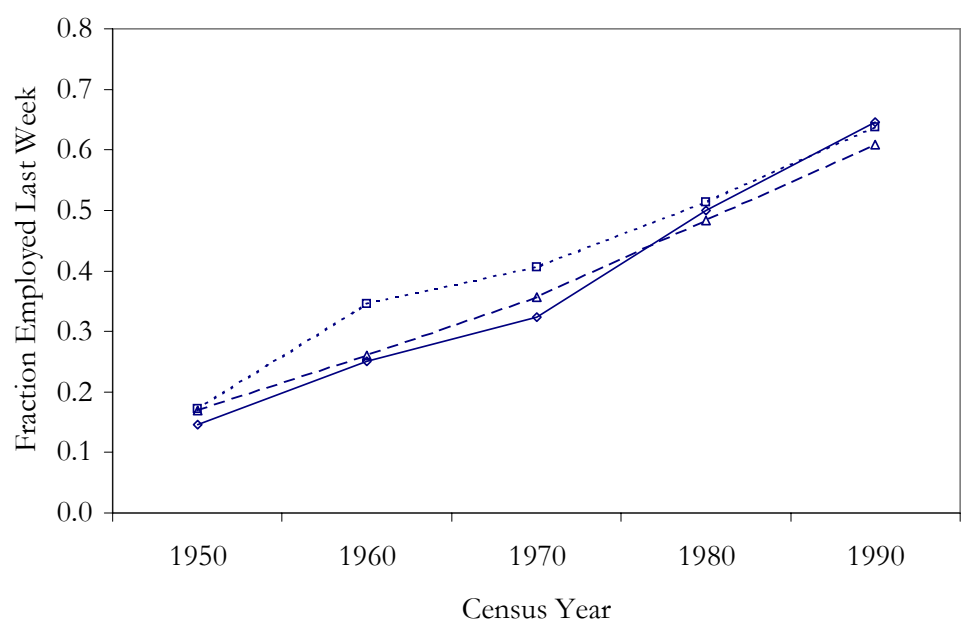

C. Employment of Comparison Group: Has 3 or 4 Year Old $\rightarrow$ 1960-69 Adopters - $₫-1970-79$ Adopters ․ㅜ $\cdots$ 1980-89 Adopters

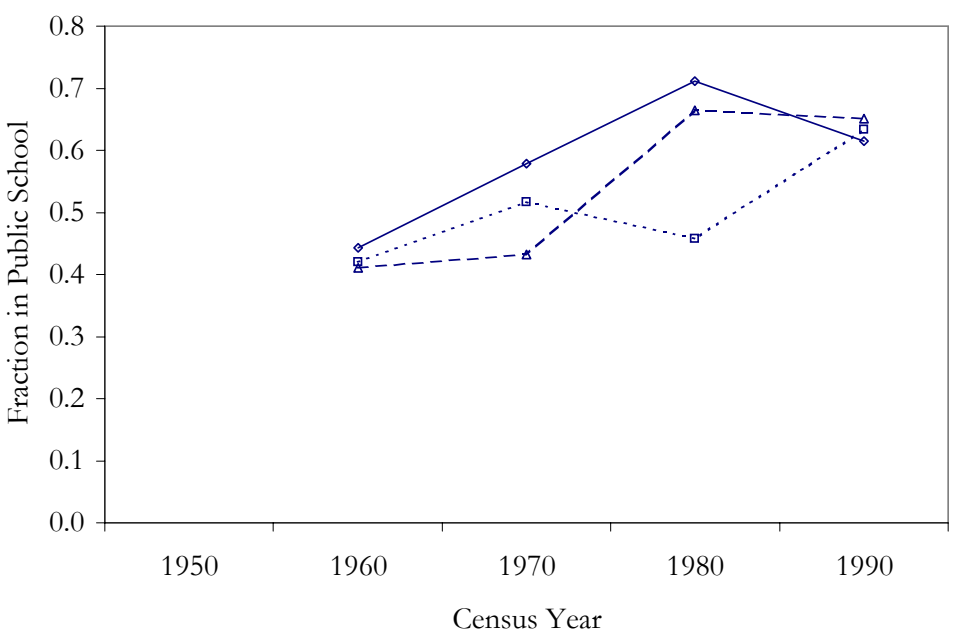

B. Enrollment of Treatment Group: 5 and 6 Year Olds

$\rightarrow$ 1960-69 Adopters - $\rightarrow-1970-79$ Adopters $\cdots a \cdots 1980-89$ Adopters

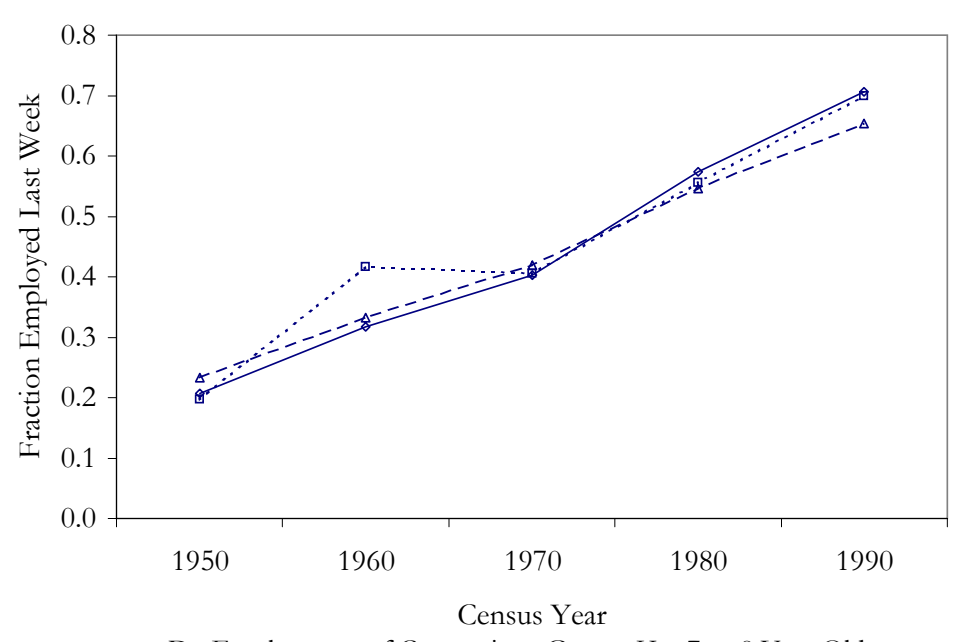

D. Employment of Comparison Group: Has 7 or 8 Year Old

\section{Figure 3}

Employment and Child Enrollment: Married Mothers of Five and Six Year Olds with No Younger Children 